\title{
Towards an Approach to Early Modern Privacy: The Retirement of the Great Condé
}

\author{
Mette Birkedal Bruun
}

In 1676 the Prince de Condé, Louis II de Bourbon-Condé, known as le Grand Condé (1621-1686) retired from his position as general in the army of Louis XIV (1638-1715) and withdrew to his country seat, the Château de Chantilly. Several contemporary commentators described Condé's move as a withdrawal into a vie privée. ${ }^{1}$ The biographers' choice of words invites the question whether Condé's retirement can be said to be a case of private life, let alone an instance of privacy. The answer to this question is a hearty 'no'. In his retirement Condé was neither alone nor enveloped by secrecy nor protected from prying

* This research has been conducted at the Danish National Research Foundation Centre for Privacy Studies (DNRF 138). I am thankful to my colleagues whose research into notions of privacy and the private in the early modern period is a constant source of inspiration; a special thank you goes to Frank Ejby Poulsen and Lars Nørgaard. Thanks are due also to Lee Palmer Wandel as well as Michael Moriarty, Emma Gilby, Nicholas Hammond, John O'Brien, and the participants of the Early Modern French seminar at the University of Cambridge for a fruitful discussion of an early stage of the study of Condé.

1 In print, the first association of vie privée with Condé seems to have been made in Rapin René, Du grand ou du sublime dans les mours et dans les differentes conditions des hommes (Paris, Sebastien Mabre-Cramoisy: 1686) 51-66. The term was also applied in Guillaume Daubenton's funerary oration, Oraison funebre de tres-haut, et tres-puissant prince Louis de Bourbon prince de Condé (Dijon, Jean Ressayre: 1687) 24-25, while vita privata appeared in the Latin version of the two letters on the life and death of Condé that were written in French by François Bergier and translated into Latin by Saligny Louis de, De morte Ludovici Borbonii Principis Condcei primi regio sanguine principis; et de prceclare ab eodem in vitâ gestis, epistolce duce (Paris, Jean François Dubois: 1689). Finally two biographies of the early 169os saw in Condé's vie privée a highpoint of his, somewhat meandering, trajectory, Coste Pierre, Histoire de la vie de Louis de Bourbon, prince de Condé, vol. 2 (Cologne, $\mathrm{F}^{* * * * * *}$ : 1693) 564-580, here 565, 571; La Brune Jean de, Mémoires pour servir à l'histoire de Louis de Bourbon, prince de Condé, vol. 2 (Cologne: Pierre Marteau, 1693) 356-406, here 357. We shall return to these texts below. Other key representations of Condé's retreat without the epithet privée, appear in Saint-Evremond Charles, "Sur la retraite de Mr. le Prince de Condé à Chantilly. Stances irregulières", in Oeuvres meslées, vol. 4 (London: 1711) 263-264; La Fontaine Jean de, "Comparaison d'Alexandre, de César et de Monsieur le Prince”, ed. P. Clarac, CEuvres diverses (Paris: 1942) 68o-692. 
gazes - whichever way we want to define privacy. In Condés world, vié privée was a quasi-technical term the meaning of which came close to the Latin privatus understood as being without civic office. The words 'privacy' and 'private life' sit uncomfortably with a historical study of early modern France because of their heavy twenty-first-century charge. Nonetheless I propose that the representations of Condé in his vie privée offer a significant contribution to the history of the notion of privacy and that one representation even features an instance of what we may choose to call early modern privacy.

In 1890 the jurists Warren and Brandeis famously defined privacy as 'the right to be let alone.' ${ }^{2}$ This definition, itself a product of historical circumstances, became legally and, to some extent conceptually, normative and still serves as a reference point. ${ }^{3}$ Warren and Brandeis's definition is but one moment in the history of privacy, ${ }^{4}$ but it may serve as an epochal moment which brings together, on the one hand, a term that derives from the Latin privatus and has travelled through centuries in linguistically varied shapes, and, on the other hand, a human phenomenon that is to do with experiences of withdrawal, boundary drawing, and control of access. ${ }^{5}$ The term and the

2 Warren S.D. - Brandeis L.D., "The Right to Privacy", Harvard Law Review 4.5 (189o) 193-220. As Vincent has noticed, this definition is not particularly relevant for a longer historical perspective, Vincent D., Privacy: A short History (Cambridge: 2016) 8. For a discussion of Warren and Brandeis's definition by the light of the early modern situation, see Korpiola's chapter in this volume.

3 For the context of Warren and Brandeis's article, the interest of the press in the lives of prominent citizens and the technological potential to pry into these lives offered by cameras, as well as its legal consequences, see Glancy D.J., "The Invention of the Right to Privacy", Arizona Law Review 21.1 (1979) 1-39; Prosser W., "Privacy", California Law Review 48.3 (1960) 383-423.

4 For example, the definition of privacy as the right to be let alone had already been couched two years earlier by Judge Cooley, Warren - Brandeis, "The Right to Privacy" 195.

5 The absence of a stable definition of privacy easily leads us into a cul-de-sac of definitory attempts, assumptions, and hairsplitting. Roughly speaking, definitions fall in two categories. On the one hand, we have efforts to define what privacy is, e.g., Altman's open understanding that 'privacy is a boundary control process whereby people sometimes make themselves open and accessible to others and sometimes close themselves off from others' Altman I., "Privacy Regulation: Culturally Universal or Cultural Specific?", Journal of Social Issues 33.3 (1977) 66-84, here 67 or Margulis's more directed and specific argument that 'Privacy, as a whole or in part, represents control over transactions between person(s) and other(s), the ultimate aim of which is to enhance autonomy and/or to minimize vulnerability' Margulis S.T., "Conceptions of privacy: Current Status and next Steps", Journal of Social Issues 33.3 (1977) 5-21, here 10; Nissenbaum's more socially embedded definition of the right to privacy as the 'right to appropriate flow of personal information' determined by a 'contextual integrity' which honours the importance of context for the determination of the notion of appropriateness from case to case, Nissenbaum H., Privacy in Context: Technology, policy, and the integrity of social life (Stanford, CA: 2010) 127-243, here 127 (Nissenbaum's italics). 
phenomenon have distinct histories, and each of these histories is prolific and multifaceted. The history of the term 'privacy' hinges on words in a variety of languages which derive from the Latin privatus, their cognates, their direct or indirect definitions and deployments as well as their connotations in specific linguistic and cultural conditions; we trace this history of the term in texts. Each occurrence comes with a context tinged with historical circumstances, intertextual references, and specific chains of transmission and translation. ${ }^{6}$ With its Latin roots and its transmission in Western languages, socio-political circumstances and institutions, the terminology of privacy can arguably be understood as having a Western origin and character which is based on the development of, not least but not only, the distinction of public and private. ${ }^{7}$ Some of the terms related to privacy and the private become concepts in their own right. This applies, for example, to vie privée. The history of the phenomenon that we sometimes call 'privacy', that is, the practice and experience of withdrawal, boundary drawing, and control of access, goes by way of artifacts, spatial markers, and vestiges of social practices; we trace it in a wide array of historical signs of human lives, actions, and experiences. The phenomenon

On the other hand, we have efforts to distinguish categories of privacy in order to reach a comprehensive, yet subtle mapping, such as the decisional, informational, and local privacy defined in Roessler B., The Value of Privacy (Cambridge: 2005 [German 2001]), paraphrased in Roessler B., "Three Dimensions of Privacy", in Van Der Sloot B. - Groot A. de (eds.), The Handbook of Privacy Studies: An Interdisciplinary Introduction (Amsterdam: 2018) 138-141. See also the four types of privacy identified by A.F. Westin in the classic Privacy and Freedom (New York: 1967): solitude, intimacy, anonymity, and reserve.

6 For a perceptive view of terminological and semantic fluctuations embedded in particular periods and languages and the impact of such fluctuations on research into notions of the private in imperial Rome, see Winterling A., "Öffentlich'und 'privat' im kaiserzeitlichen Rom”, in Schmidt T. - Schmitz W. - Winterling A. (eds.), Gegenwärtige Antike - antike Gegenwarten. Kolloquium zum 6o. Geburtstag von Rolf Rilinger (Munich: 2005) 223-244, here 226-235.

7 See, e.g., Weintraub's claim that 'Drawing the lines between public and private - both practically and theoretically - has been a central preoccupation of Western thought since classical antiquity' Weintraub J., "Preface", in Weintraub J. - Kumar K. (eds.), Public and Private in Thought and Practice: Perspectives on a Grand Dichotomy (Chicago - London: 1997) xi-xvii, here xi, elaborated in Weintraub J., "The Theory and Politics of the Public/Private Distinction", in Weintraub - Kumar (eds.), Public and Private 1-42. Viewing this dichotomy from a non-Western perspective, scholars have suggested that the notion of privacy is poorly compatible with, e.g., the African regard for ubuntu, Makulilo A.B., "The Context of Data Privacy in Africa", in Makulilo A.B. (ed.), African Data Privacy Laws (Cham: 2016) 3-23, or the Japanese esteem for self-denial, Nakada M. - Takanori T., "Japanese Conceptions of Privacy: An Intercultural Perspective", Ethics and Information Technology 7.1 (2005) 27-36. 
of privacy can possibly be understood as having some universal resonance, albeit with widely diverse manifestations and implications. ${ }^{8}$

In some instances, the history of the term and the history of the phenomenon converge, but often they run in separate tracks, each of them multifarious. If we want to study historical notions of privacy, we need to be clear whether we study the history of the term or the history of the phenomenon. In this chapter I sketch approaches that support each of these two avenues. The first part of the chapter traces themes and figureheads in the research on the term and the phenomenon, ending in a presentation of the dual work method of the Centre for Privacy Studies. In the second and third parts, I exemplify this dual approach through an examination of the representations of Condé's vie privée.

Part I: Approaching Privacy

\subsection{Approaching the Private}

Research into the history of the term 'privacy' is linked to research into the private and related notions. There is no dearth of sociological and philosophical analyses that touch upon privacy and the private as well as the implications and historical evolution of these concepts. Such approaches share a tendency to deploy the notion of '(the) private' and its counterparts, most often 'public', as a vehicle for the identification of, for example, societal dynamics or practices in a given historical period, a longue durée development, or epochal shifts that herald the early stages of modernity. A quick overview will give us an idea of the legacies that principal paradigms among such analyses leave students of privacy to tackle.

For Norbert Elias (1897-1990), a still keener delineation of a private sphere is inherent to the process of civilisation. Elias engages the distinction between private and public in his analysis of the ways in which the courtly ideals of the centralised early modern state spurred on the identification of a private realm. This realm, according to Elias, was the result of an increasing sensitivity to the actions and manners that were deemed shameful and disgusting and of the refinement of techniques fit to curb and isolate such actions and manners. ${ }^{9}$ In

8 As discussed in Altman, "Privacy Regulation"; this is also the assumption underlying the socio-historical case studies of privacy in Moore Jr B., Privacy: Studies in Social and Cultural History (Armonk, NY: 1984); see also Westin's two chapters on "Privacy in the Animal World" and "Privacy in the Primitive World", Privacy and Freedom 8-19.

9 Elias's seminal longue durée analysis was published in German in 1939 as Wandlungen des Verhaltens in den Weltlichen Oberschichten des Abendlandes (vol. 1) and Wandlungen der 
Elias, the segregation of the private becomes one vehicle for the identification of such techniques. ${ }^{10}$

Hannah Arendt (1906-1975), in her The Human Condition (1958), takes a gendered approach to the distinction of polis and oikos (city-state and home or household), and identifies the latter as a sphere of inequality and thus the less honourable of the two. ${ }^{11}$ Arendt's distinction forms the basis of a wider discussion which is not our concern here; suffice it to notice the foundational reaffirmation of the Aristotelian association of the domestic sphere with female agency, spurring on a host of scholarship that tends to equal privacy with domesticity and female chores and interests. ${ }^{12}$

Jürgen Habermas (1929-) builds on Arendt in his seminal propagation of the eighteenth-century emergence of the public sphere which came with an inherent, almost off-hand, definition of Privatheit as 'saturated and free interiority':

Das Selbstverständnis des öffentlichen Räsonnements ist spezifisch von solchen private Erfahrungen geleitet, die aus der publikumsbezogenen Subjektivität der kleinfamilialen Intimsphäre stammen. Diese ist der geschichtliche Ursprungsort von Privatheit, im moderne Sinne gesättigter und freier Innerlichkeit. ${ }^{13}$

The public's understanding of the public use of reason was guided specifically by such private experiences as grew out of the audience-oriented (publikumsbezogen) subjectivity of the conjugal family's intimate domain

Gesellschaft:Entwurf zu einer Theorie der Zivilisation (vol. 2). It was republished in German in 1969 as Über den Prozess der Zivilisation.

10 See, e.g., his description of how the bedroom "ist zu einem der "privatesten" und "intimsten" Bezirke des menschlichen Lebens geworden' ('one of the most "private" and "intimate" areas of human life') and his statement that the visible and invisible walls of the nuclear family 'entziehen das "privateste", "intimste", 'das ununterdrückbar "Tierische" im Dasein des einen Menschen den Blicken der anderen' ('withdraw the most "private", "intimate", insuppressibly "animal" aspects of human existence from the sight of others'), Elias N., Über den Prozeß der Zivilisation: Soziogenetische und psychogenetische Untersuchungen, vol. 1 (Frankfurt a.M.: 1981 [1969]) 222; transl. E. Jephcott, Elias N., On the Process of Civilisation: Sociogenetic and Psychogenetic Investigations (Dublin: 2012) 16o.

11 Arendt H., The Human Condition (Chicago - London: 2018 [1958/1998]).

12 For a historical nuancing of Arendt's view, see Becker A., Gendering the Renaissance Commonwealth (Cambridge: 2019) and its discussion of home and marriage as a political topos in the early modern period.

13 Habermas J., Strukturwandel der Öffentlichkeit: Untersuchungen zu einer Kategorie der bürgerlichen Gesellschaft (1962) (Frankfurt a.M.: 2018 [1990]) 87. 
(Intimsphäre). Historically, the latter was the source of privateness in the modern sense of a saturated and free interiority. ${ }^{14}$

Habermas links this domestic and nuclear-family cradle of privacy to the Roman notion of privatus, and defines the home as the primary locus of the citizen who is without public office. Any notion of privacy or the private that features in Habermas's mapping of an Öffentlichkeit is but a residual category of his main project, but while the Habermasian Privatsphäre, its agents, and their businesses remain on the horizon as factors that influence the public sphere and shape its discourses, he generally segregates the private sphere as a zone which is of little interest to the powers that rule, implicitly or explicitly, the public dimension of society. Nowhere is this more explicit than in his somewhat basic diagnosis of early modern religion as something that, in the aftermath of the sixteenth-century reformations, became a Privatsache..$^{15}$

Elias, Arendt, and Habermas share, albeit variously, the tendency to deploy notions of privacy and the private as, at once, an analytical catalyst which supports their longue durée expositions and also a form of result, the emergence or reemergence of which is a component in their overall identification of historical signifiers of modernity. Habermas and Elias are particularly important foils for this volume given their shared conviction that the eighteenth century, that is, the latest part of our chronological focus, is a watershed for the distinction of public and private. ${ }^{16}$ Without necessarily challenging their position, several chapters may be said to explore instances related to a pre-history of this watershed.

14 Translation by Burger T. - Lawrence F., The Structural Transformation of the Public Sphere: An Inquiry into a Category of Bourgeois Society (Cambridge: 1989) 28, parentheses from the translation.

15 Habermas, questionably, avers that 'Die sogenannte Religionsfreiheit sichert geschichtlich die erste Sphäre privater Autonomie' ('The so-called freedom of religion historically secured the first sphere of private autonomy'), Habermas, Strukturwandel 67; transl. Burger - Lawrence, The Structural Transformation 11-12.

16 A view corroborated by Koselleck who, in the Kritik und Krise: eine Studie zur Pathogenese der bürgerlichen Welt (Freiburg - Munich: 1959), defines the sixteenth-century wars of religion as the source of the segregation of public and private, agreeing with Habermas's view that the peace of Westphalia was instrumental in delineating a private space of unhindered beliefs and practices. For a paraphrase and discussion of Habermas and Koselleck from the point of view of privacy studies, see Brewer J.D., "This, That and the Other: Public, Social and Private in the Seventeenth and Eighteenth Centuries", in Castiglione D. - Sharpe L. (eds.), Shifting the Boundaries: Transformation of the Languages of Public and Private in the Eighteenth Century (Exeter: 1995) 1-21, here 1-8. 
A fourth paradigmatic sociological foil is Foucault's scrutiny of the encounter of individuals with themselves, each other, the powers that be, and techniques wielded in this encounter. While neither Habermas nor Elias has much time for religion, throughout his oeuvre Foucault has a keen eye on the religious dimension of (self)surveillance and its inherent negotiation and transgression of some form of privacy. The segregation of public and private and the ruptures of this segregation are not his primary focus, but emerge as an accompanying interest. This finds a word for word expression in his charting of the extension of the direction of souls (la conduction des âmes) from pastoral to political power. Speaking of the sixteenth-century development of the government of human beings beyond the realm of pastoral authority, Foucault avers that it is exactly the problematisation and specification of different forms of conduct that spur on the segregation of public and private. ${ }^{17}$ However, a dynamic between public or publicised and private or interior may also be said to underlie his interest in the techniques of self inherent in the Christian confession. ${ }^{18}$

This sketch reminds us that distinctions of public and private are pertinent landmarks in grand-scale chartings of societal structures and their fluctuations. Such distinctions offer structural insights that may inspire and enlighten our historical analysis even when the historical conjectures may seem inadequate. The private is a useful analytical category because it is heavily laden with meaning and yet pliable enough to denote conditions that are personal, domestic, family-related, hidden from public view, interior, and so forth. Sociological and philosophical analyses as those noted here rely on generalisations that can provoke historians who tend to shun grand narratives in preference of indepth analysis attuned to nuances and particularities. ${ }^{19}$ Some historians have

17 Foucault M., Sécurité, territoire, population: Cours au Collège de France (1977-1978) (Paris: 2004) $235^{-23} 6$, here 236 .

18 See, e.g., Foucault M., "About the Beginning of the Hermeneutics of the Self: Two Lectures at Dartmouth", Political Theory 21.2 (1993) 198-227.

19 A historian may wince when, e.g., in his investigation of the dichotomy private/ public, Bobbio avers that "Through constant and continuous use, and without any substantial changes, they have since become one of the "great dichotomies" used by several disciplines [...] to define, represent and order their particular fields of investigation'. Bobbio N., "The Great Dichotomy: Public/Private", in Bobbio N., Democracy and Dictatorship: The Nature and Limits of State Power (Minneapolis, MN: 1989 [Italian 1985]) 1-21, here 1, my underlining. Historians have pointed out that Habermas's theory of the public sphere is inconsistent with historical insights, see for a feminist evaluation, e.g., Francus M., Monstrous Motherhood: Eighteenth-Century Culture and the Ideology of Domesticity (Baltimore, MD: 2012) and Landes J.B., Women and the Public Sphere in the Age of the French Revolution (Ithaca: 1988); for sharp warnings against deploying Habermas's 
however, ventured into sweeping overviews of privacy and the private in ways that pay some respect to this disciplinary demand for detail. Ariès and Duby's seminal five-volume Histoire de la vie privée holds pride of place. ${ }^{20}$ This collective work offers a longue durée bird's eye view of the phenomenon of privacy. It brings together a broad array of themes rooted in a twentieth-century understanding of private life, and each volume presents figures, texts, and images pasted together in a thought-provoking study of domesticity, hygiene, sex, interiority, family, space, religion, leisure, and the like. Other historians have followed suit, generally tending to move directly from some notion of privacy,

philosophical approach as a yardstick for historical studies, see, e.g., Bellany A., The Politics of Court Scandal in Early Modern England: News Culture and the Overbury Affair, 1603-1660 (Cambridge: 2012) and Cowan B., "Rethinking Habermas, Gender and Sociability in Early Modern French and British Historiography”, in Vanhaelen A. - Ward J.P. (eds.) Making Space Public in Early Modern Europe: Geography, Performance, Privacy (New York: 2013) 41-53; see also the historical nuances suggested in the essays in Wilson B. - Yachnin P. (eds.), Making Publics in Early Modern Europe: People, Things, Forms of Knowledge (New York: 2011); for an overturning of Habermas's observations regarding early modern salons and coffeehouses, see, Lilti A., Le Monde des Salons: Sociabilité et Mondanité à Paris au XVIII ${ }^{e}$ siècle (Paris: 2005) and Cowan B., The Social Life of Coffee: The Emergence of the British Coffeehouse (New Haven, CT: 2005). But Habermas's work has also inspired more sympathetic modification such as Merlin-Kajman H., Public et littérature en France au $X V I I^{e}$ siècle (Paris: 1994) which adds historical nuance and conceptual sophistication to the blanket notion of the public; see also Merlin-Kajman's chapter in this volume. For historical studies inspired by Habermas, see also Freise F., "Einleitung", in Emmelius C. Freise F. - von Mallinckrodt R. - Paschinger P. - Sittig C. - Toepfer R. (eds.), Offen und Verborgen: Vorstellungen und Praktiken des Öffentlichen und Privaten in Mittelalter und Früher Neuzeit (Göttingen: 2004) 9-32 and the essays in Castiglione D. - Sharpe L. (eds.), Shifting the Boundaries: Transformation of the Languages of Public and Private in the Eighteenth Century (Exeter: 1995). Mention must finally be made of the momentous investigation of the seventeenth- and eighteenth-century emergence of the publicprivate divide, offering a prehistory, as it were, to the Habermasian notion with an English focus, in McKeon M., The Secret History of Domesticity: Public, Private, and the Division of Knowledge (Baltimore, MD: 2005) as well as the discussions and extensions of McKeon's insights in Cowan B. - Yetter L. (eds.), Publicity and Privacy in Early Modern Europe: Reflections on Michael Mckeon's The Secret History of Domesticity, special issue of History Compass 10.9 (2012).

20 Ariès P. - Duby G. - Chartier R. (eds.), Histoire de la vie privée, 5 vols. (Paris: 1985-1987). Of particular interest in our context is the third volume: Chartier R. (ed.), De la Renaissance aux Lumières (Paris: 1986). Medieval and early modern instances of private and the private have since then been analysed in Melville G. - von Moos P. (eds.), Das öffentliche und private in der Vormoderne (Cologne - Weimar - Vienna: 1998), and the history of privacy as self-determination, viewed as the prehistory of privacy as data protection, has been traced in Schmale W. - Tinnefeld M.-T., Privatheit im digitalen Zeitalter (Cologne: 2014). See also the chapters by Merlin-Kajman and Wunder in this volume. 
or the absence thereof, into the archive and back again without necessarily engaging in much conceptual mediation. ${ }^{21}$

Notions of privacy and the private remain fascinating to historians and historically inclined sociologists. It is a token of the catalytic potency of the term and the phenomenon that they continue to lend themselves as analytical keys to studies of core dimensions of historical societies and existences. Seen from the perspective of early modern studies, it is no less interesting that the conclusions of such studies vary. Some studies identify a wide array of early modern instances of a heuristically defined understanding of the private life; some present substantiated convictions that there is no such thing as early modern privacy. ${ }^{22}$ It seems to be a general challenge to approach early modern notions of privacy in a way that keeps in mind overall societal structures as well as diachronic changes and continuities, while paying heed to the historical details and specificities that emerge from particular archives, prints, cases, contexts, and circumstances.

\subsection{Centre for Privacy Studies}

This methodological quandary is one of the spurs for the scholars at the Centre for Privacy Studies. ${ }^{23}$ Rather than beginning from an overall interest in societal

21 See in particular the collaboratively ambitious Pardailhé-Galabrun A., La naissance de l'intime: 3000 foyers parisiens XVII ${ }^{-}-X V I I I^{e}$ siecles (Paris: 1988) which appeared in English under the suggestive title The Birth of Intimacy: Privacy and Domestic Life in Early Modern Paris (1992). This comprehensive work proposes to document a revolution in the perception and furnishing of the home ${ }^{1725^{-1775}}$. It is illuminating on the level of social detail, but engages quite a straddle in its argumentative movement from archival minutiae to grand conclusions. Less strain is employed in Orlin L.C., Locating Privacy in Tudor London (Oxford: 2008). Orlin sets out her dynamic understanding of privacy from the beginning 'Personal privacy takes many forms: interiority, atomization, spatial control, intimacy, urban anonymity, secrecy, withholding, solitude', Locating Privacy 1 . She continues with a sobering review of Ariès, Chartier, and Duby's more ebullient approach to the sources. Instead she turns to a specific case and the related legal and municipal records in search for the boundaries and possibilities of privacy, mapping the limits of spatial and informational privacy, desired and distrusted, with a critical eye to anachronistic assumptions regarding past people's motives. For studies of privacy, and the lack thereof, viewed through legal documents, see the chapters by Klein Käfer, Korpiola, and Laflamme in this volume.

22 For an example of the latter, see Rothstein's contribution to this volume.

23 The Centre for Privacy Studies is funded by the Danish National Research Foundation (DNRF 138) and housed at the Theological Faculty of the University of Copenhagen in collaboration with the Royal Danish Academy - Architecture, Design, Conservation in Copenhagen. The Centre was founded in 2017 and is directed by Mette Birkedal Bruun; in April 2021 it houses some 23 postdoctoral scholars and PhD-students from architectural history, church history, history of political ideas, legal history, and social history. 
structures, we take our point of departure in the historical documents. When we set out from cases and sources rather than from a more or less subtle definition, we gain and we lose scholarly precision. ${ }^{24}$ We gain a proximity to the historical material and an access that is not mediated by more or less fortunate definitory efforts. An approach that takes its semantic apparatus entirely from the sources, however, loses the conceptual precision honed in a definition. In order to avoid atomisation, we need to linger over the questions: What are we looking for when we are looking for notions or privacy and the private? How do we recognise them when we find them?

A terminological approach is an immediate response to this question. This approach is concerned with rriv $^{*}$ words, that is, words that derive from privatus, and it owes something to the methods of the Begriffsgeschichte outlined by Reinhart Koselleck and his colleagues, with the immediate caveat that a term is not necessarily a concept. ${ }^{25}$ Are we to approach the matter systematically, we may, as Koselleck reminds us, take our point of departure either in the semasiological concern with the array of meanings of a given term or a set of terms, or in the onomasiological focus on the array of terms used to denote a particular phenomenon. ${ }^{26}$ Taking the semasiological route, we look for words such as privacie, privautez, in privato, and Privatperson, but with a view to semantic cognates related to, e.g., secrecy and intimacy. Such words give us coordinates

The principal research focus is directed to notions of privacy and the private in Western Europe (1500-180o), but we reach out to a geographically and chronologically wider span of research interests through seminars and collaborations. The Centre is driven by a vision of collaborative and interdisciplinary research, and the scholars approach eleven research cases in teams, working from their individual disciplinary perspective, but within an overall methodological horizon sketched in this chapter. The work on the cases relies on site-based analysis which is, however, not the concern here. The aim of the Centre for Privacy Studies is not to reach a conceptual definition or theory of privacy, but to gain insights pertaining to the interactive influence of a wide array of historical factors on terms and phenomena related to privacy, be they stable and robust or ephemeral and malleable.

24 I am indebted to the keen analysis of the distinction of public and private in von Moos P., 'Öffentlich' und 'privat' im Mittelalter: Zu einem Problem der historischen Begriffsbildung (Heidelberg: 2004); see also the studies in von Moos, Öffentliches und Privates, Gemeinsames und Eigenes (Berlin: 2007).

25 Koselleck R., "Einleitung", in Brunner O. - Conze W. - Koselleck R. (eds.), Geschichtliche Grundbegriffe: Historisches Lexicon zur politisch-sozialen Sprache in Deutschland, vol. 1 (Stuttgart: 1972) XIII-XXV, here XX-XXI. See, for a first presentation of the approach of the Centre for Privacy Studies, Bruun M.B., "Privacy in Early Modern Christianity and Beyond: Traces and Approaches", Annali Istituto storico italo-germanico/Jahrbuch des italienisch-deutschen historischen Instituts in Trient 44.2 (2018) 33-54. 
in a diverse and open-ended multi-lingual vocabulary which, etymologically and in some instances semantically, is connected to the term 'privacy'.

The Latin roots of this terminology have a key aspect of negation. Privatus is, above all, deployed to indicate the opposite of that which is public, official, professional, communal, or evident. ${ }^{27}$ The English term privacy emerges in the mid-fourteenth century, ${ }^{28}$ but German, Dutch, French, Italian, and the Scandinavian languages do not have a substantive which covers the same implications; instead we get composite words based on adjectival combinations such as Privatsphäre, Privatandacht, and Privatperson ${ }^{29}$ or vie privée, oraison privée, and droit privé. ${ }^{30}$ The terminological approach is purist and reductionist in that it grasps only one dimension of the field we are interested in, but as Peter von Moos reminds us, it is less exposed to anachronism with its firm grounding in the Quellensprache, the language of the source. ${ }^{31}$

Priv ${ }^{*}$ words do not necessarily bring us to the phenomenon of privacy. In order to encircle this dimension, we need a different take. We may detect in the historical sources instances that smack of creating, invading, or protecting some form of privacy. Given the airy definitory status of 'privacy', an onomasiological approach is not quite to hand. At the Centre for Privacy Studies we study the segregations and distinctions that happen in particular zones and at the thresholds between them, be they lasting or ephemeral. ${ }^{32}$ These heuristic zones serve as an analytical tool that helps us to examine the early modern phenomena, practices, and experiences of withdrawal, boundary drawing, and control of access that we may, for operational ease, subsume under the term

27 According to Lewis and Short, privatus derives from the verb privo, 'to bereave, deprive, rob, strip of anything' or 'to free, release, deliver from anything'; its principal meaning is related to being 'apart from the State, peculiar to one's self, of or belonging to an individual, private (opp. publicus or communis; cf. domesticus)' and the term denotes persons who are not in office and things, such as houses, that are isolated from State affairs, Lewis C.T. - Short C., A Latin Dictionary (Oxford: 1891 [1879]) 1447. According to Russell, the earliest datable distinction of publicus and privatus appears in Plautus (ca. 254-184 BC), Russell A., The Politics of Public Space in Republican Rome (Cambridge: 2015) 30.

28 Huebert R., "Privacy: The Early Social history of a Word", The Sewanee Review 105 (1997) 21-38, here 28 .

29 See Zedler Johann Heinrich, Grosses vollständiges Universal-Lexicon aller Wissenschaften und Künste, vol. 29 (Halle - Leipzig, Verlegts Johann Heinrich Zedler: 1741) cols. 559-585.

30 For the French language, see Merlin-Kajman's chapter in this volume.

31 Von Moos P., "Die Begriffe 'öffentlich' und 'privat'", Saeculum 49 (1998) 161-192, here 163.

32 Scholarship on theories and principles of privacy and the private, some of which has been discussed above, help us to define these zones. For a more extensive description, see Bruun M.B., "Work Method". https://teol.ku.dk/privacy/research/work-method/privacy _work_method.pdf/PRIVACY_Work_Method_Acces.pdf, accessed on 15 October 2020. 


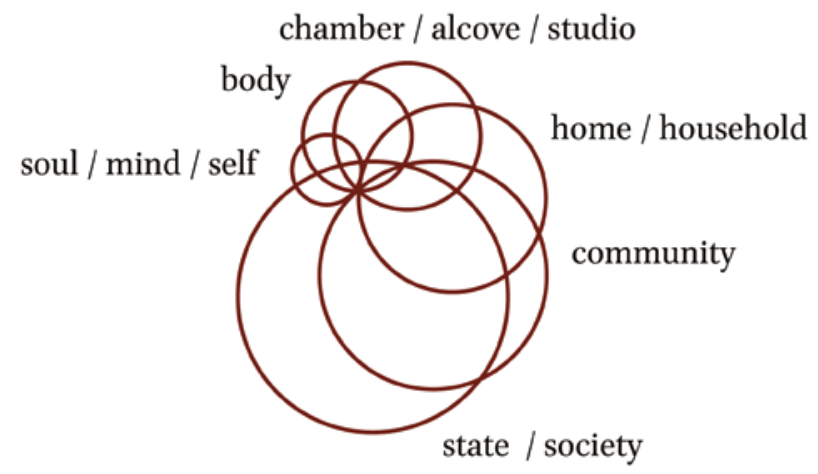

FIGURE 2.1 The heuristic zones

privacy, and the ways in which these phenomena are delineated, negotiated, and curbed. ${ }^{33}$

The heuristic zones are shaped on the basis of a concentric structure [Fig. 2.1]. This structure bears resemblance to Roessler's onion model and its layers of personal/bodily intimacy, family, society, and the state as the public realm, ${ }^{34}$ but it is more attuned to the early modern period with its distinction of body and soul and the chamber as separate zones. When we fan out the circles or layers, however, we achieve a more intricate grid which is better fitted to ferreting out finer details, since the heuristic zones then offer not only the distinct domains of society, community, household, and so forth, but also thresholds and overlaps between them. Rather than providing answers, the zones help us to ask questions such as: What happens at a given threshold, say, between community and home? Who is allowed to cross the threshold and when? Who controls this access and by which technologies (doors, locks, keys, but also invitations, hierarchically diversified rights of access etc.)? Is it an escalation of privacy when someone enters a chamber? Is the chamber restricted in terms of, for example, access, activities, and knowledge? The zones also prompt us to pay heed to overlaps. Again, the aim is less to find answers than to hone the questions. Is there a difference between forging rebellion in the body, that is, in action, and having rebellion in mind? By what means and how forcefully does, say, a given ruler of a state regulate each of these two zones?

33 The heuristic zones may be considered a graphic pendant to Brewer's insight that a fruitful analysis of the public and the private must pay attention not to the polarity of public and private, but 'to the spaces in between - those areas, borders or boundaries which repeatedly shift and which are repeatedly crossed', Brewer, "This, that and the other" 10.

Roessler B., The Value of Privacy (Cambridge: 2005) 13. 
Where are the boundaries of some form of privacy and by what means are they created? ${ }^{35}$ Asking such questions does not lead us directly to historical notions of privacy, but they do help us to understand when, why, and how phenomena of withdrawal and boundary control are negotiated, reinforced, or abolished in specific early modern cases.

Neither the terminological approach, nor the analytical deployment of the heuristic zones offers a direct path to historical knowledge. But these two methods help scholars from different research fields to establish a joint and quite pragmatic apparatus for the joint scrutiny of a composite source material, and thus they offer a common analytical lens that is fit to bring out and analyse historical insight from various disciplinary angles. Since these two approaches are but work methods, it takes historical cases, figures, and contexts to discover their strengths and weaknesses. The descriptions of the great Condé's retirement provide one such case.

\section{Part II: The vie privée of le grand Condé}

3.1

Condé: A Biographical Sketch

We are interested in the implications of vie privée in select texts on the Great Condé, the Prince de Condé, Louis II de Bourbon-Condé, not in Condé as a historical person, ${ }^{36}$ not in the fabrication of Condé as a grand-siècle

35 This is the focus of PRIVACY scholar Anni Haahr Henriksen's research on the mind as an inward private space in Elizabethan England, Henriksen A.H., "'Consciences are not to bee forced, but to bee wonne': The Inward Turn in Elizabethan Homiletic Discourse and the Legal Debate over the Ex Officio Oath in the Court of High Commission, 1570-1593", in Skouvig L. - Marklund A. (eds.), Histories of Surveillance from Antiquity to the Digital Age: The Eyes and Ears of Power (Abingdon: 2021) 37-52.

36 The great Condé has been the subject of a steady stream of biographies of a more or less literary character. The first were closely connected to the house of Condé; Joseph Louis Ripault-Desormeaux, the librarian of a later prince of Condé authored the fourvolume Histoire de Louis de Bourbon, prince de Condé (1766-1768); Henri d'Orléans Aumale, who inherited the castle of Chantilly and its archive wrote the nine-volume Histoire des princes de Condé aux XVI e et XVII e siècle (Paris: 1863-1896); and Henri Malo, curator at Chantilly authored Le Grand Condé (Paris: 1937). Among more recent biographies are Bertière S., Condé: Le héros fourvoyé (2011); Pujo B., Le grand Condé (Paris: 1995); Blancpain M., Monsieur le Prince: La vie illustre de Louis de Condé, héros et cousin du Grand roi (Paris: 1986); and Duhamel P., Le Grand Condé ou l'orgeuil (Paris: 1981). For a socio-economical analysis of the seventeenth-century Condé clan, see Béguin K., Les princes de Condé: Rebelles, courtisans et mécènes du Grand siècle (Seyssel: 1999). These works share an interest in Condé's character and historical circumstances while we are above all interested in the representation of the prince. Bannister's important study of 
hero. ${ }^{37}$ That said, a brief sketch of our protagonist is in order. Until the birth of the later Louis XIV in 1638 , the great Condé was third in the royal succession, and he remained a powerful, and problematic, factor in the state hierarchy. ${ }^{38}$ His triumph at the age of 21 in the battle at Rocroi in 1643 launched his reputation as a war hero, which was consolidated through a series of victories in the Thirty Years War. His palace in Paris and his chateau in Chantilly some $5^{\circ} \mathrm{km}$ north of Paris became centres of Condés scientifically and culturally precocious court characterised by libertine interests and outlooks. ${ }^{39}$ The Fronde saw Condé wavering in his allegiance to the king, leading to his imprisonment in 165o; eventually, he offered his service to the Spanish king. In our context, these turbulent years are mainly of interest as the jarring backdrop for later portrayals of his loyalty. Condé returned to France and the grace of Louis XIV in 1659 and was once again put in charge of the royal army, celebrating victories in the Franco-Dutch war alongside the second great commander of the time, Turenne.

The period of interest here begins in 1676 when Condé withdrew from his military career and settled at Chantilly. The king's principal gardener and landscape architect André Le Nôtre (1613-1700) had worked on the park since the early 166os, and in the early 1670s Condé turned to the castle with the assistance of Jules Hardouin-Mansart (1646-1708).40 Condé succeeded where Nicolas Fouquet (1615-1680) had failed. He developed a splendid mansion with

the representations of Condé, has two chapters dedicated to portrayals during his retirement and immediately after his death; these chapters, however, do not ponder the notion of vie privée which Bannister translates straightforwardly as 'his private life', Bannister M., Condé in Context: Ideological Change in Seventeeth-Century France (Oxford: 2000) 174-213, esp. 187-213, here 19o. I owe several references to Bannister's work.

37 This facet has been examined in Bannister, Condé in Context. For Condés selfstaging, see Kühner C., "Il va de ma vie, de mon honneur et par conséquent de tout'. Die Selbstinszenierung des Grand Condé", in Asch R.G. - Emich B. - Engels J.I. (eds.), Legitimation - Integration - Korruption: Politische Patronage in Früher Neuzeit und Moderne (Darmstadt: 2011) 115-130.

38 For implications and manifestations of this position, see Kühner C., Politische Freundschaft bei Hofe: Repräsentation und Praxis einer sozialen Beziehung im französischen Adel des 17. Jahrhunderts (Göttingen: 2013) 77 and Kühner, "Il va de ma vie'”.

39 Béguin K., "Lacadémie du Grand Condé: un asile de la liberté scientifique?", in Demeulenaere-Douyère C. - Brian É. (eds.), Règlement, usages et science dans la France de l'absolutisme (Paris - London - New York: 2002) 25-35.

40 This elaborate renovation of gardens and buildings is described in Aumale, Histoire des princes de Condé vol. 7, 701-708. For Mansart's work at Chantilly, see Jestaz B., "Documents sur l'œuvre de Jules Hardouin-Mansart à Chantilly”, Bulletin Monumental 149.1 (1991) 7-75. For a representation of the castle and its gardens at its most lavish, see the report of the feast given by Condé's son to the Dauphin in 1688, i.e. two years after Condé's death in Visé Jean Donneau de, La Feste de Chantilly. Contenant tout ce qui s'est paßé pendant le 
lavish waterworks the construction of which dovetailed with, and inspired, the works at Versailles, without challenging the king. ${ }^{41}$ At Chantilly Condé continued to gather around him a vivacious, diverse, and anti-dogmatic court of artists, scientists, theologians, philosophers, and poets..$^{42}$ Madame de Sévigné observed that 'Monsieur le Prince est dans son apothéose de Chantilly' ('at Chantilly M. le Prince is at his high point').$^{43}$ While theological debates were the order of the day, and religious figureheads flocked to his court, piety was not a hallmark of this life.

This was to change. At Easter 1685 Condé sought out the Jesuit Étienne-Agard Deschamps (1613-1710), an acquaintance from the military past, and after five days in seclusion with the priest, the prince allegedly received Communion and apologised to his staff for having been such a bad example. According to the memorialist Louis François du Bouchet de Sourches (1645-1716), this caused surprise, for it had been 17 years since Condé's last Communion. ${ }^{44}$ The last year of his life Condé spent increasingly tormented by gout and adamantly working to secure a good standing with the king for his heirs. These efforts culminated in the union of his grandson Louis de Bourbon (1668-1710) with Louis XIV's natural daughter with Mme de Montespan, Louise-Françoise, Mlle de Nantes (1673-1743). The marriage was celebrated at Versailles in 1685. It was Louise-Françoise's sickness from smallpox that drew Condé to Fontainebleau where he died on 11 December 1686 - but only after having sent to the king a letter that attested to his respect, his devotedness, and his tenderness for the majesty. ${ }^{45}$

\subsection{Retraite in Seventeenth-Century France}

Our study of representations of Condés vie privée adds to a body of research into grand-siècle spaces, practices, and ideals of retreat. ${ }^{46}$ Bernard Beugnot,

sejour que Monseigneur le Dauphin y a fait, avec une description exacte du Chasteau \& des Fontaines (Lyon, Thomas Amaulry: 1688).

41 Kühner, "Il va de ma vie'" 127.

42 Béguin, "Lacadémie du Grand Condé". The diverse circle and its spirited exchanges as well as Condé's artworks and books are described in detail and with verve in Aumale, Histoire des princes de Condé, vol. 7, 686-701.

43 Letter to Mme de Grignan of 21 July 1677, in Madame de Sévigné, Correspondance, ed. R. Duchêne, vol. 2 (Paris: 1978) 501.

44 Bernier A. (ed.), Mémoires secrets et inédits de la cour de France sur la fin du règne de Louis XIV par le Marquis de Sourches, vol. 1 (Paris: 1836) 88-90.

45 The letter is printed in La Brune, Mémoires, book 7, vol. 2, 380.

46 See, e.g., Beugnot B., Loin du monde et du bruit: Le discours de la retraite au XVII siècle, 2nd ed. (Paris: 2015 [1996]); "Loisir, retraite, solitude: de l'espace privé à la littérature", in Fumaroli M. - Salazar P.J. - Bury E. (eds.), Le loisir lettré à l'âge classique (Geneva: 1996) 
who looms large in this research field, pursues the seventeenth-century French discourses of retreat and solitude along three tracks. He considers them partly as the resurfacing of an inherited trope which is retrieved in order to fulfil a particular cultural function; partly as a phenomenon that is lived and expressed in particular socio-political contexts; and, finally, as a literary theme which has the power to inform the organisation and rhythm of a text, ${ }^{47}$ averring that in seventeenth-century French poetry, la solitude is a genre that comes with a particular horizon of expectations. Most studies of retreat are either indifferent to, and silent on, the notion of the vie privée or treat it as a past parallel to presentist understandings. ${ }^{48}$ Even Beugnot's chapter 'Fores et genres de l'espace privé 49 does not delineate this private space, and none of the quotations given in the chapter features the word privé $(e)$. He does, however, come close to a definition of privé in his description of religious poetry as belonging to the 'sphère des genres privés' ('the sphere of private genres') in its capacity as a genre that does not address a group (society, court, salon), but rather

173-195; and "Y a-t-il une problématique féminine de la retraite?", in Leiner W. (ed.), Onze études sur l'image de la femme dans la littérature française du dix-septième siècle (Tübingen: 1978) 29-49. For solitude as a literary, religious, and philosophical trope, see Beauvalet-Boutouyrie S., La solitude: XVII ${ }^{e}-X V I I I^{e}$ siècle (Paris: 20o8) and Naudin P., L'expérience et le sentiment de la solitude dans la littérature française de l'aube des Lumières à la Révolution (Paris: 1995); for solitude as the politically tinged locus of a worldrenunciation connected to as diverse motives as the pursuit of inner peace, the religious renunciation of the civic corollaries of the Fall, and the libertin quest for a natural moral code, see Battista A.M., "Morale 'privée' et utilitarisme politique en France au XVII siècle", in Lazzeri C. - Reynié D. (eds.), Le pouvoir de la raison d'État (Paris: 1992) 191-230, here 198-200; for otium and the ethos of retreat as a driver of critical literary engagement from the sideline, as it were, see Schneider R.A., Dignified Retreat: Writers and Intellectuals in the Age of Richelieu (Oxford: 2019); for religious implications of solitude see, finally, my "Prayer, Meditation, and Retreat", in Lyons J.D. (ed.), The Oxford Handbook of the Baroque (Oxford: 2018) and "A Solitude of Permeable Boundaries: The Abbey of La Trappe between Isolation and Engagement", in Göttler C. - Enenkel K.A.E. (eds.), Solitudo: Spaces, Places, and Times of Solitude in Late Medieval and Early Modern Europe (Leiden: 2018) 451-479. See for a critical overview of research, Goodman D., "Public Sphere and Private Life: Toward a Synthesis of Current Historiographical Approaches to the Old Regime", History and Theory 31.1 (1992) 1-20.

47 Beugnot, Loin du monde 30-31.

48 As when Fumaroli observes that the seventeenth-century Parisian hôtels were dedicated to the private life (la vie privée) and the intimate leisure involved in this life, Fumaroli M., "Otium, convivium, sermo: La conversation comme lieu commun", in Fumaroli M. Salazar P.J. - Bury E. (eds.), Le loisir lettré à l'âge classique (Geneva: 1996) 29-52, here 46; or when Beugnot succinctly identifies the tensions in the opening of Corneille's l'Illusion comique (1636) between 'deux espaces, l'extérieur et l'intérieur, le public et le privé' ('two spaces: the exterior and the interior, the public and the private') Beugnot, Loin du monde 2. Beugnot, Loin du monde 71-82. 
the inner life of individuals who practise their religion in the secrecy of their chamber or oratory. ${ }^{50}$

Instead of attempting to throw light on a general phenomenon, drawing on a diverse sample of sources, this chapter uses a particular example as a paradigmatic prism for some of the early modern associations of the term privé $(e)$. The occurrences of the term privé(e) that we shall encounter in the selected sources are but few and of a somewhat contingent nature. At the same time occurrences such as these accumulate in the Imaginaire of notions of the private in seventeenth-century France and beyond. ${ }^{51}$ The representations of Condé's retirement as a vie privée refer to a model, but they also contribute to the tracing of that model's pliable contours.

\subsection{Condé's Vie Privée: The Motifs}

We shall look briefly at three texts on Condé which have in common the deployment of the term vie privée. Being different in character and genre, they will give us a first idea of a stock repository of connotations of vie privée as well as the scope of variation. The earliest work in focus is René Rapin's $D u$ Grand ou du Sublime dans les mours (1686). ${ }^{2}$ In this text, Rapin (1621-1687), one among a significant number of Jesuits in Condé's circle, ${ }^{53}$ takes Condé as the key example of the sublime vie privée over against the king's sublime vie publique in one of the juxtapositions of life-forms so dear to the age. ${ }^{54}$ Rapin is

$50 \quad$ Ibidem, 81 .

51 For the concept of the imaginaire, see Le Goff J., Limaginaire médiéval: essais (Paris: 1985) I-VIII. Le Goff uses the term to denote a psychologically coded register concerned with images which are collectively relevant. I use it in a sense more attuned to the literary and rhetorical set of tropes than to a shared psychological repository or to the profound societal claims made in Castoriadis C., L'Institution imaginaire de la société (Paris: 1975).

$5^{2}$ Rapin René, Du grand ou du sublime dans les moeurs et dans les differentes conditions des hommes (Paris, Sébastien Mabre-Cramoisy: 1686).

53 For Rapin's proximity with Condé, see, e.g., Dubois E., René Rapin: L'homme et l'ouvre (Lille: 1970) 77-84; Bannister, Condé in Context 193, 203. While his sister, the duchesse de Longueville, Anne-Geneviève de Bourbon (1619-1679), ended her life as a friend of Port-Royal, Condé, who began his education at a Jesuit college, and would commend the education of his son and grandson to that same Order, ever verged towards the Jesuits, Dubois, René Rapin 77. His Jesuit circle included, among others, Nicolas Talon (16o11691) who was since long associated with Condé's family, as well as François Bergier and Étienne-Agard Deschamps, whom we shall return to.

54 See, for Rapin's work on this text and its inspiration from Longinus, Dubois E., René Rapin 567-581; the year after, in 1686, Rapin expanded his portrait of Condé in Le Magnanime in response to criticism that his praise of Condé's military pursuits had not been sufficiently rich, Dubois, Renée Rapin 81-84, 581-587. For the genre of vies comparées, see Beugnot, Loin du monde 53-65; Rapin's work is not among Beugnot's examples. 
interested in the sublime as a moral rather than a rhetorical category, averring that it is better to explore how people can perfect the mores in their respective conditions than to learn how to speak well. ${ }^{55} \mathrm{He}$ conjures up an image of the ideal heroic vie privée, evoking several cognates along the way, for example, 'glorieux repos' ('honourable repose') and 'vie particuliere \& retirée' ('individual and withdrawn life'). ${ }^{56}$ For Rapin, the sublime nature of Condé's retreat is intimately connected to its public recognition, and he concludes the opening of his section on Condé with the following phrase:

Cette vie douce \& paisible que mene ce Prince en sa retraite, est un nouveau genre de Sublime qui peut-estre n'a pas d'éxemple: \& je ne sçay si le lait \& le village ont jamais esté dans une si haute considération, qu'il les a mis. Car toute la France va faire sa cour à ce village $[\ldots] .57$

This sweet and peaceful life that this Prince undertakes during his retreat is a new version of the sublime, which perhaps has not been seen before: I do not know if the milk and the village have ever been valued so much as he has made them be; all of France wants to settle their court in this village.

The next text is a funeral sermon. On 11 December 1686, Condé died at Fontainebleau. His death elicited a series of memorial services and accompanying eulogies. A lavish ceremony was held in Notre-Dame on 10 March 1687;

55 Rapin, Du Grand ou du Sublime unpaginated 'Avertissement'. For a brief condensation of Rapin's sense of the sublime, but with a focus on his Réflexions sur la poétique de ce temps (1675), see Martin E.M., "The 'Prehistory' of the Sublime in Early Modern France: An Interdisciplinary Perspective", in Costelloe T.M. (ed.), The Sublime: From Antiquity to the Present (Cambridge: 2012) 77-102, here 77. The discussion of the sublime becomes an argument in the debate between, on the one hand, Boileau and his view of the sublime as a rhetorical category and, on the other hand, Huet, but also Rapin, and the view that the epithet sublime can be applied to things and morals. For the positions in this debate, see Declercq G., "Boileau-Huet: La querelle du Fiat Lux", in Guellouz S. (ed.), Pierre-Daniel Huet (1630-1721). Actes du colloque de Caen (Tübingen: 1994) 237-262; Gilby E., Sublime Worlds: Early Modern French Literature (London: 2006); Lyons J.D., "Sublime Accidents", in Wine K. - Lyons J.D. (eds.), Chance, Literature, and Culture in Early Modern France (Farnham: 2013) 95-109.

56 Rapin, Du Grand ou du Sublime 64-65.

57 Ibidem, $5^{1-52}$. Rapin had followed Condé's retreat with critical interest and already in 1676 commented in a letter to Bussy that his retreat was that of a philosopher, not that of a Christian, Dubois, René Rapin 78. Condé followed a diet that relied heavily on cow's milk on account of his gout, La Brune, Mémoires, book 7, 362; Dubois, René Rapin 577. Translations are mine unless otherwise stated. 
at it, Jacques-Bénigne Bossuet (1627-1704) delivered his famous panegyric. ${ }^{58}$ On 26 April 1687, Condé's heart was interred at the Jesuit Church in Rue Saint-Antoine in Paris. The event was accompanied by a sermon held by another chief orator, Louis Bourdaloue $\left(163^{2}-1704\right)$ that was much praised at the time. ${ }^{59}$ A host of memorial services and funerary orations waxed eloquent on Condé's retreat to Chantilly and its ultimate penitential flavour, ${ }^{60}$ but only Guillaume Daubenton (1648-1723) who had delivered his sermon in the Jesuit church in Dijon on 28 February 1687 talked about it as a vie privée. ${ }^{61}$ Daubenton is particularly intent on showing Condé's progressive evolution towards becoming a penitent Christian who died the good death. He links the vie privée with terms related to religious retreat, thus evoking a prevailing discourse in the religious temper of the period.

$5^{8}$ It was printed as Oraison funèbre de tres-haut et tres-puissant prince Louis de Bourbon, prince de Condé, premier prince du sang. Prononcée dans l'église de Nostre-Dame de Paris, le 10. jour de mars 1687 (Paris, Sébastien Mabre-Cramoisy: 1687). Mme de Sévigné details the abundant furnishing of the church in a letter to Bussy-Rabutin of 10 March 1687, in Correspondance, vol. 3, 283-284.

59 It was printed as Oraison funebre de tres-haut et tres-puissant prince Louis de Bourbon, prince de Condé, premier prince du sang (Paris, E. Michallet: 1687). Mme de Sévigné gives an enchanted paraphrase in a letter to Bussy-Rabutin begun on 25 April 1687, Correspondance, vol. 3, 290-293.

6o See the list of the primary orations in Bannister, Condé in Context 212-213.

61 It was printed as Oraison funebre de tres-haut, et tres-puissant prince Louis de Bourbon prince de Condé (Dijon, Jean Ressayre: 1687). Daubenton was a rising star when he delivered his oration. Since 168 o he was confessor to Louis XIV's daughter-in-law Marie Anne Christine de Bavière (166o-169o); he was considered as confessor for her oldest son, the Dauphin (1682-1712) and would later become confessor to her second son, Philippe V of Spain (1683-1746) and play an active part in the Roman flanks of the campaign against the Jansenists. When he held his funeral oration for Condé, he was assisting various Jesuit houses as preacher and confessor, known, among other feats, for his funeral orations; he spent 1686 in Dijon. For Daubenton's biography, see Désos C., Biographie du P. Guillaume Daubenton, confesseur de Philippe V d'Espagne (1643-1723) 4-5. Projet PLUTARCO XXI. 2010. ffhal-01861658f. https://hal.archives-ouvertes.fr/hal-o1861658/docu ment (accessed on 29 July 2020). Condé inherited the post as governor of Burgundy from his father, but following the arrest of the prince in 1650, Mazarin removed him from office. The prince returned in 166o, but never stayed much in Dijon and ceded the office to his son in the late 166os, see Breen M.P., Law, City, and King: Legal Culture, Municipal Politics, and State Formation in Early Modern Dijon (Rochester: 2007) 97-127; Nachison B., "Absentee Government and Provincial Governors in Early Modern France: The Princes of Condé and Burgundy, 166o-1720", French Historical Studies 21.2 (1998) 265-297, here 269-270. Daubenton makes as much as he can of Condé's attachment to Dijon, mentioning that the prince brought several banners to one of the Dijonnais churches after his illustrious victory at Rocroi in 1643 and boasting Condé's lingering bonds to the region, Oraison funèbre 12, 32-33. 
In the early 169os appeared a pair of Condés biographies authored by two Protestants, Pierre Coste (1668-1747) and Jean de La Brune (or Labrune) $\left(1653^{-1736) .}{ }^{62}\right.$ Condé's relationship to Protestants is not our interest here. ${ }^{63}$ Suffice it to say that he welcomed Protestant figures at his court, but that he also seems to have taken an interest to secure conversions in the aftermath of the Revocation of the Edict of Nantes, and received from friends and staff reports about conversions among his old company, ${ }^{64}$ the staff of his houses, ${ }^{65}$ and the inhabitants on his land. ${ }^{66}$ As our third example, we shall concentrate on Jean de La Brune's Mémoires, one book of which is dedicated to how Condé retreated to Chantilly 'pour y mener une vie privée' ('in order to entertain a private life there'). ${ }^{67} \mathrm{La}$ Brune sees himself as a compiler rather than an author. ${ }^{68}$

62 Coste Pierre, Histoire de la vie de Louis de Bourbon, prince de Condé, 2 vols. (Cologne, $\mathrm{F}^{* * * * * *}:$ 1693); La Brune Jean de, Mémoires pour servir à l'histoire de Louis de Bourbon, prince de Condé, 2 vols. (Cologne, Pierre Marteau: 1693).

63 See, for one side of this story, the dispatches that concern the revocation of the Edict of Nantes in Gonin F. - Delteil F., "La Révocation de l'Edit de Nantes vue par les informateurs du Grand Condé", Bulletin de la Société de l'Histoire du Protestantisme Français 118 (1972) 115-117, 118-172, and 354-382 and Bulletin de la Société de l'Histoire du Protestantisme Français 119 (1973) 90-115, 287-301, and 400-418. The Protestant past of the clan may underlie Coste's choice of topic, which is mispresented in Rumbold's claim that Coste's biography of Condé was 'undoubtedly' spurred on by Condé being Protestant, Rumbold M.E., Traducteur huguenot: Pierre Coste (New York: 1991) 36-37. Coste does not recoil from mentioning that Condé's first education was in the hands of two Jesuits, Coste, Histoire 10. La Brune is more explicit. He mentions the execrable murder of Condé's grandfather Louis I who, in La Brune's words, headed the discontent faction in the wars of religion. He continues with a description of the conversion of Condé's father, Henri, in the suit of the conversion of King Henry IV which made him so zealous for his new religion that, according to his posthumous reputation, the main purpose of his birth was to reestablish the Catholic religion that his father had wanted to destroy. As La Brune remarks, it is not surprising that Henri sent Condé to the Jesuit collège in Bourges at the age of eight, La Brune, Mémoires, book 1, vol. 1, 10.

64 See, e.g., Letter 142, from de Puysieux to Condé of 10 January 1686, in Gonin - Delteil, "La Révocation" 370.

65 See, e.g., Letter 246 , from Guerard to Condé of 18 January 1686 , in ibidem, $381-382$.

66 See, e.g., Letter 202, from Richard to Condé of 4 December 1685, in ibidem, 156; Letter 51, from La Proustière to Condé of 4 January 1686, in ibidem, 359.

67 La Brune, Mémoires, book 7, 357.

68 He explains that his work is based on memoirs of members of Condé's staff and letters by people with access to Chantilly as well as a collection of historical texts, some of which have been published before, La Brune, Mémoires, vol. 1, Avertissement, unpaginated $[3,8]$. Before the Revocation, La Brune had been minister to Mme de Vignoles close to Montpellier, and afterwards he became minister in the Netherlands. He published a Traité de la justification based on a translation of Calvin's Institutes (1693), Stelling-Michaud S. (ed.), Le livre du recteur de l'Academie de Genève (1559-1878), vol. 4 (Geneva: 1975) 233; Krumenacker Y., "Les églises de la barrière", in Krumenacker Y. (ed.), Entre calvinistes et 
Among the sources listed in the avertissement only Rapin, François Bergier, and the funeral orations deal with Condé's retreat, and it is probably Rapin's treatment of Condé's vie privée that above all resonates in de La Brune's text. If Rapin is bent on exalting Condé, de La Brune declares it his ambition to draw a fidèle portrait. ${ }^{69}$ We learn not only of the prince's genius for warfare, but also of his bad and irregular teeth, frequent but unpleasant laughter, and the bitter, difficult, and stormy temper that tended to ruin the gifts that fortune and nature had bestowed upon him. ${ }^{70}$

The funerary orations were not the last attempt to secure a pious repute for the sometime libertine Condé. Three years after his death appeared $D e$ morte Ludovici Borbonii Principis Condcei, written in French by François Bergier (1622-1688) and translated into Latin by Louis de Saligny (1657-1723), both Jesuits. ${ }^{71}$ The French text, our fourth example, does not speak of vie privée, but instead allows us to compare a French and a Latin terminology employed to speak about Condé's withdrawal. Where Bergier had vie retirée, Saligny put vita privata, reminding us that vie privée has cognates worth including in our search and that translations broaden the terminological scope..$^{72}$

The selected texts exemplify key clusters of connotations evoked by the term vie privée. These representations may be, to use Agnès Walch's term, medialisations of the vie privée, but they are a far cry from any revelation of scandals, secrets, and intimate details. ${ }^{73}$ Their aim is not to stir but to confirm; less to pry open than to augment the contours of a stylised ideal. While much in Condés libertine life and penchant for intellectual pleasures resembles Epicureanism, ${ }^{74}$ it is above all Ciceronian tenets of civic virtue and retreat as

catholiques: les relations religieuses entre la France et les Pays-Bas du Nord: XVI ${ }^{e}-X V I I I^{e}$ siècles (Rennes: 2010) 345-365, here 351.

69 La Brune, Mémoires, book 7, 393.

70 Ibidem, 393-395.

71 Bergier - de Saligny, De morte Ludovici Borbonii. For the close relationship between Condé and Bergier and the work, see Bannister, Condé in Context 205-206.

72 Bergier - de Saligny, De morte Ludovici Borbonii 310-311, 170-171. See also the description of Condé's attempts to convert his Protestant servants by talking to them privatim/en particulier $182-183$.

73 See Walch A. (ed.), La médiatisation de la vie privée ( $X V^{e}-X X^{e}$ siècle) (Arras: 2012).

74 Charles de Saint-Evremond was in Condés military service and belonged to his circle of interlocutors in the period $1642-1648$, which, according to Potts, was the natural precursor of Saint-Evremond's turn to Epicurism, Potts D., Saint-Evremond: A Voice from Exile - Unpublished Letters to Madame De Gouville and the Abbe De Hautefeuille 1697-1701 (Abingdon - New York: 2017 [Oxford: 2002]) 1-4; see also Manning Hope Q., SaintEvremond and his Friends (Geneva: 1999) 37-6o. For the seventeenth-century libertins as heirs to Epicureanism, see Ford, P., "Lucretius in early modern France", in Gillespie S. Hardie P. (eds.), The Cambridge Companion to Lucretius (Cambridge: 2010 [2007]) 227-241. 
a fertile soil for such virtues that resonate in the representation of Condés retirement in our, prevalently Jesuit, authors. ${ }^{75}$ The occurrence of such direct and indirect references is to some extent connected, as products and producers, to the seventeenth-century revitalisations of the classical tradition, contributing to its delineation as well as to what Beugnot has called its mobilisation and actualisation. ${ }^{76}$ The selected texts are not primarily voices in the ongoing discussion of the merit or dangers of classical philosophical schools and position. ${ }^{77}$ While some of the ideas of self-mastery resonate with Stoic ideals, none of the texts come close to, for example, François de Sales's explicit endorsement of the practices of self-insight that were proposed by the

75 Cicero had a central place in the Jesuit ratio studiorum (from 1599), and was favoured not least because of the civic values of his oeuvre; contrary to Ambrose and Jerome who had seen the Ciceronian otium as a withdrawn observation of the world, the Jesuits viewed it as the foundation of action, Maryks R.A., Saint Cicero and the Jesuits: The Influence of the Liberal Arts on the Adoption of Moral Probabilism, (Aldershot: 2008) 83-97. See also O'Malley's statement that De officiis was a work well-known by any Jesuit and treasured for its message of civic harmony, O'Malley J.W., "Introduction: The Pastoral, Social, Ecclesiastical, Civic and Cultural Mission of the Society of Jesus", in O'Malley J.W. Bailey G.A. - Harris S.J. - Kennedy T.F. (eds.), The Jesuits II: Cultures, Sciences, and the Arts, 1540-1773 (Toronto: 2006) xxiii-xxxvi, here xxxii. Cicero's independence of philosophical schools is propagated in, e.g., Rapin René, Reflexions sur la philosophie ancienne et moderne, Et sur l'usage qu'on en doit faire pour la Religion (Paris, François Muguet and Claude Barbin: 1676) 27, 150-151.

76 Beugnot, Loin du monde 77 .

77 Rapin lashes out at the Stoics as epitomes of showy pride, excepting Epictetus as the most reasonable and sincere Stoic; he also charges Epicurus with having put on a show of austerity to gloss over his voluptuous doctrine and appear more palatable, Rapin, Reflexions sur la philosophie 139-143 (on Zenon and the stoics); 143-148 (on Epicurus); 151 (on Epictetus). Furthermore, he takes Lipsius to task for his ready Christianisation of Stoic ideals (142). Rapin's stance is in contrast to the Jesuit predilection for the Stoics argued in, e.g., d'Angers, J.-E., "Le stoïcisme d'après l'Humanitas theologica de Pierre Lescalopier (1660)", Bulletin de littérature ecclésiastique $5^{6}$ (1955) 23-36, 147-161. The stoic apatheia was generally a bone of contention for Christian commentators, but especially difficult to accept for the staunchest Augustinians who found that Stoicism led to Pelagianism, see d'Angers, "Le stoïcisme" 147, see also 149, 153-58; Brooke C., Philosophic Pride: Stoicism and Political Thought from Lipsius to Rousseau (Princeton NJ: 2012) 78, but also Rapin trots out the view the Stoicism is redolent of pride, and we should stay wary of too easy factioning, Rapin, Reflexions sur la philosophie 142-143. For seventeenth-century philosophical and, above all, Christian appropriations of Stoicism, see the æuvre of Julien-Eymard d'Angers. For seventeenth-century, French anti-Stoic currents based in Augustinianism and thus related to, but not restricted to, Port-Royal, see Brooke, Philosophic Pride 76-100; see also Moriarty M., Early Modern French Thought: The Age of Suspicion (Oxford: 2010 [2003]) 198 , pointing to the anti-stoic sentiment of Malebranche, Pascal, La Rochefoucauld, and La Bruyère. 
philosophical traditions. ${ }^{78}$ The casual glance at classical antecedents on the following pages does not equal any strong claim of direct references to the said antecedents, since this would require substantial analyses of book holdings and documented reading. Such references serve merely to underline the longevity and modulations of the discourse of the private life.

A swift scan of three general themes will give us a first sense of just how charged and kaleidoscopic the semantic scope of the notion of vie privée is. Thus we now turn to Condé's vie privée as a locus of, respectively, retirement from civic duties, self-mastery, and penitential solitude.

\subsubsection{Retirement from Civic and Military Duties}

The etymological origins of vie privée rest with the Roman civitas. The term vie privée refers to the meaning of privatus as being without a civic office, ${ }^{79}$ and in our context it denotes Condé's situation as retired; when he withdraws from his military office, he does, in Bergier and Saligny's terms, become a private person (privatum hominem / un particulier). ${ }^{80}$ The vie privée is twinned with the term retraite, retreat, which sits comfortably with the military ambience of his life and grandeur. ${ }^{81}$ Arguably exploiting the military connotations of retreat, La Brune lists three potential motifs for Condé's retraite which featured in contemporary speculation - all of them strategic. ${ }^{82}$ Some people claimed that the princely general withdrew because his bodily frailty prevented him

${ }_{7} 8$ De Sales underlines the value of the examen de conscience recommended by Seneca, Plutarch, and the Pythagoreans, de Sales François, Traité de l'amovr de Diev, book 2, chap. 18 (Lyon, Pierre Rigaud: 1616) 196. He calls the Stoics the most virtuous of the philosophers, ibidem, 198. The Stoics, according to de Sales, and in particular his preferred Stoic Epictetus, base their entire philosophy on abstention and renunciation of pleasures and worldly honours and train themselves to bear labours and lack of comfort; but the Christian teaching, which is the only true philosophy, bases all exercises on three principles: to exercise self-denial, to carry one's cross, and to follow Christ in all sorts of good deeds. Christ's passion is the apex of these principles, ibidem, book 9, chap. 2, 472. De Sales's discussion of the Stoics goes via Augustine's representation in De civitate $D e i$, books IX and XIX. For de Sales's Christian appropriation of Stoic viewpoints, see d'Angers J.-E., L'Humanisme Chrétien au XVII e siècle: s. François de Sales et Yves de Paris (The Hague: 1970).

79 Von Moos, “'Öffentlich' und 'privat' im Mittelalter” 13; Winterling “'Öffentlich' und 'privat' im kaiserzeitlichen Rom" 224.

8o $\quad$ Bergier - de Saligny, De morte Ludovici Borbonii 312-315.

81 See, for example, Rapin, Du Grand ou du Sublime 5o; Daubenton, Oraison funèbre, e.g., $25^{-26}$, featuring six mentions of 'retraite' in two pages; see also La Brune, Mémoires, book 7,261 .

82 As a general, Condé was known for his genial fougue, his impetuous fire, rather than for any strategic caution, the latter being rather the hallmark of Condé's fellow commander, Turenne, Bannister, Condé in Context 211. 
from paying the king due respect at court which might be deemed a lack of veneration. ${ }^{83}$ Others suspected that having won much glory on the battlefield, he was now aiming for the glory of solitude. Yet others believed that, since the king had not forgotten Condé's treason and sometimes showed signs of resentment, Condé decided to remove himself from the royal gaze so as to avoid hampering the fortune of his son, the duke d'Enghien. ${ }^{84}$ In harmony with this military tenor, our texts are at pains to show that Condé's retirement is a heroic feat on a par with, or even superior to, his triumphs in war, and Rapin is representative of all our authors when he ascribes to Condés withdrawal an organic addition of honour, avowing that 'aprés avoir aquis tout l'honneur qu'on peut aquerir dans la guerre, il a eû encore le bonheur d'aquerir par sa retraite tout celuy que peut faire la paix ${ }^{85}$ ('after having achieved all the honour that can be gained in war, he had also had the fortune to achieve, by his retreat, all that [honour] which peace can bring about').

Just like his martial feats, Condé's retreat elicits commonplace comparisons. While allusions to Alexander the Great ornament portrayals of his military endeavours, ${ }^{86}$ the definitive model of his retirement becomes the Roman general Scipio Africanus the Elder (236-183 BC), a preeminent paradigm of the Roman otium in its positive variant. Scipio retreated to Liternum in Campania close to Naples around 185 BC and spent the last years of his life there. The identification of Scipio's retreat as an almost mythical origin of the discourse of retreat has some historical footing, ${ }^{87}$ but it was not least the ensuing centuries of representations that led to his status as an icon of withdrawal which

83 I owe the awareness to the strategic implications of non-military retreat to Judith Frömmer and the SF B 1015: Muße: Grenzen, Raumlichkeit, Praktiken at the Albert-LudwigsUniversität Freiburg; sincere thanks for a first exchange are due to Prof. Frömmer and to her colleague Andrea Guidi.

84 La Brune, Mémoires, book 7, 357-359. None of our texts compare retirement from office to military retreat, but the comparison does appear in Girardot de Nozeroy, Raisonnement fait par le Conseiller G. de N. retiré en sa maison où il mourut, edited in 1638-1650, published in Perrod, M., Le livre de la retraite du sieur Girardot de Nozeroy (Lons-le-Saunier: 190o), and discussed in Beugnot, Loin du monde $75^{-76}$.

85 Rapin, Du Grand ou du Sublime 54. Loyal to the eulogistic genre, Menestrier explains that the retired general was more heroic in his penitential preparations for death than he had been on the battlefield, Ménestrier Claude-François, La Source glorieuse du sang de l'auguste maison de Bourbon dans le coeur de saint Louis, roy de France. Sujet de l'appareil funèbre pour l'inhumation du coeur de très-haut [...] prince Louis de Bourbon, prince de Condé (Paris, E. Michallet: 1687) 15 .

86 Bannister, Condé in Context e.g. 33-34, 85.

87 André identifies the historical Scipio as a first mover in the deployment of the otium as a period dedicated to physical repose for his soldiers; his own exercise of otium also entailed a purification of the mind that prepared him for action, André J.-M., L'Otium 
underlies Rapin's allusion. In this tradition, the Ciceronian mention of the general's regular, and temporary, retreat into self-reflection merged with Livy's portrait of Scipio's daily retreats and Seneca's epithet of the general's last and lasting retirement into that spartan lodging in Liternum. A quick overview of these landmarks will give a foil for Rapin's allusion while adding a few important elements from the classical basis for notions of privacy and the private. Cicero (106 BC-43 ВС) opens the last book of De officiis with a reference to Cato's remark that Scipio was never less at leisure (otiosum) than when in leisure, and never less alone (solum) than when alone, as a cue for a discussion of public life and its contrasts. Cicero describes the Scipionic otium as a series of regular withdrawals, narrating how '[i]lle enim requiescens a rei publicae pulcherrimis muneribus otium sibi sumebat aliquando et e coetu hominum frequentiaque interdum tamquam in portum se in solitudinem recipiebat' ('For he, to find leisure from his splendid services to his country, used to take a vacation now and then and to retreat from the assemblies and the throngs of men into solitude, as into a haven of rest'). ${ }^{88}$ In Livy (59 BC-17 AD), these retreats occur on a daily basis: 'nullo die prius ullam publicam privatamque rem egit quam in Capitolium iret ingressusque aedem consideret et plerumque solus in secreto ibi tempus tereret'. ('there was not a day on which he did any business public or private without going first to the Capitol, and after he had entered the temple, sitting down and usually passing the time there alone in seclusion') ${ }^{89}$ Seneca (ca. 4 BC-65 AD) had lasting influence with his awed report from the general's tomb and austere villa in Liternum, describing the spartan bathing house as a token of the retired general's ascetic habits. ${ }^{90}$ Scipio remained an example of honourable retreat, ${ }^{91}$ and, as Leopoldine Prosperetti shows, for

dans la vie morale et intellectuelle à Rome des origines à l'époque augustéenne (Paris: 1966) $58-65$.

88 Cicero, De officiis III.1.3, in Cicero: On Duties, trans. W. Miller (Cambridge, MA: 1913) 270-272.

89 Titus Livius Ab urbe condita 26.19, in Livy, History of Rome, trans. F.G. Moore, vol. 7 (Cambridge, MA: 1943) 72-73.

$90 \quad$ Seneca, "Epistula 86", in Seneca Epistles, trans. R. Gummere, vol. 1 (Cambridge, MA: 1917) 310-318. For Seneca's identification with Scipio, see Ker J., The Deaths of Seneca (Oxford: 2010 [2009]) 325-358.

91 For example, Scipio is one of several key examples of otium and solitude in the second book of Petrarch's De vita solitaria. Bondanella J.C., 'Petrarch's Rereading of 'Otium' in 'De vita solitaria', Comparative Literature 6o.1 (2008) 14-28, here 22, 24-25. As Enenkel observes, it is particularly Scipio's ability to commune with himself (secum loqui) that interests Petrarch, in Petrarca Francesco, De vita solitaria, Buch I: Kritische Textausgabe und ideengeschichtlicher Kommentar, ed. and comm. K.A.E. Enenkel (Leiden - New York - Copenhagen - Cologne: 1990) 290-296. For the notion of otium honestum, see 
sixteenth-century humanists the African general became a Neo-Stoic protagonist of an otium that lent itself readily to Christian adaptation. ${ }^{92}$

The Scipionic austerity, however, fits poorly with Rapin's sublime version of Condé's vie privée, and the Jesuit engages the model negatively: 'La retraite du grand Scipion en sa maison de campagne proche Capoûë après avoir conquis l'Affrique \& l'Asie, n'a rien de comparable à celle de Monsieur le Prince de Condé en sa maison de Chantilly'93 ('The great Scipio's retreat to his country house close to Capua after having conquered Africa and Asia had nothing comparable to that of M. le Prince of Condé in his house in Chantilly'). He remarks that Scipio's retreat after his victories had no glory that Condé's did not outshine and that there is no comparison between a Roman citizen and a prince of blood stemming from one of the world's most ancient and illustrious houses. Daubenton, in turn, underlines not the difference, but the similarity between Condé and Scipio in one sweeping glance at Condé in action and retirement: 'Son premier soin dans la solitude, fut de former son esprit, tel dans les Armées \& à Chantilly, que fut l'illustre Scipion au Camp de Cartage, \& dans sa retraite de Capoûe'94 ('His first concern in solitude was to form his spirit: in the army and at Chantilly, just as the illustrious Scipio did it in his camp at Carthage and in his retreat in Capua'). The difference reminds us that for these authors, tradition serves as a foil for the description of the private life. This foil may be engaged in concord or disagreement, depending on the genre and authorial aims.

Condé's house and gardens in Chantilly are key components in the representations of his retirement. The representations draw somewhat in the direction of popular pastoral tropes, albeit in a courtly and highly groomed variant, praising not only horticultural and architectural pleasures of the rural mansion, but also Condé's capacity for shaping them. According to La Brune, 'Le Prince de Condé ne fut pas plûtôt retiré à Chantilly, qu'il s'attacha à orner \& embellir sa solitude de toutes les maniéres possibles: en quoy il réussit admirablement' ${ }^{\prime 95}$ ('No sooner had the prince of Condé withdrawn to Chantilly than he devoted himself to decorating and embellishing his solitude in all possible manners: in which regard he succeeded excellently'). A keyword here is solitude which may

Vickers B., "Leisure and Idleness in the Renaissance: The Ambivalence of Otium I", Renaissance Studies 4.1 (1990) 1-37, here 10-12; Schneider, Dignified Retreat.

95 La Brune, Mémoires, book 7, 362. 
not seem to us the most precise description of Chantilly's magnificence, but does evoke a whole set of associations related to rural retreat. ${ }^{96}$

Loyal to his project to display this vie privée as sublime, Rapin resorts to even grander expressions in his description of Condés ingenious and perfectly balanced plan for his house and garden:

Il falloit qu'il en fist luymesme le plan, qu'il en conceust le dessein, \& qu'il en fust l'ouvrier. Cette maison n'auroit eû rien digne de luy, si ce qu'il falloit pour l'orner \& pour l'embellir n'est passé par sa teste, \& s'il n'en eust esté luy-mesme l'ordonnateur. C'est aussi pour cela que dans l'œconomie de cette admirable solitude on voit jusques dans les ruisseaux, dans les bocages, dans les berceaux, dans les fontaines, dans les canaux, \& dans ces grand réservoirs d'eau quelques traits de la grandeur de son génie: tout y respire l'élévation de son ame, \& la politesse de son esprit, [...]. Les pensées qu'il a eûës pour parer son hermitage, sont à proportion aussi sublimes que les grandes actions qu'il a faites dans ses compagnes pour sa gloire $\&$ pour celle de l'Estat. ${ }^{97}$

He had to make the plan himself, to conceive of the design, and to be the worker. This house would have been in no way worthy of him if what it took to decorate and embellish it had not passed through his mind and if he had not himself been the manager of it all. It is also for this reason that we see traces of the magnitude of his genius in the outline of this excellent solitude - even in the streams, the groves, the arches, the fountains, the canals, the great water reservoirs - everything there breathes his soul's elevated state and the civility of his spirit $[. .$.$] . The ideas that he$

96 The beginning of the century saw a poetic turn to the rural retreats of Horace and Ovid; the forest, the meadow and the leafy grove were in vogue. The poetic idyll changes in character and connotations across the century; see Taormina M., "Noble Selfhood and Saint-Amant's Nature Poetry", in Sabean D.W. - Stefanovska M. (eds.), Spaces of the Self in Early Modern Culture (Toronto: 2012) 134-15o. The trend was augmented with Honoré d'Urfé's Astrée (1607-1627) as the key type and most influential manifestation of pastoral solitude. Towards the end of the century retreat was endowed with more complex psychological qualities, see Stanton D., "The Ideal of 'repos' in Seventeenth-Century French Literature", L'Esprit Créateur 15.1-2 (1975) 79-104, here 95-97.

97 Rapin, Du Grand ou du Sublime 57-58. It lies beyond our scope to pursue the question whether philosophical structures underlie Le Nôtre's design, propagated in Weiss A.S., Mirrors of Infinity: The French Formal Garden and 17th-Century Metaphysics (New York: 1995 [French 1992]) 79-92 and challenged in Conan M., "The New Horizons of Baroque Garden Cultures", in Conan M. (ed.), Baroque Garden Cultures: Emulation, Sublimation, Subversion (Washington DC: 2005) 1-35, here 1-3. 
had for adorning his hermitage are of the same proportion of sublimity as the great deeds that he did in his military campaigns for his own glory and that of the state.

The portrayal of Chantilly evokes the trope of the locus amoenus which, according to Curtius's classical typology, holds, as a minimum, a tree, a meadow, and a source or brook, with birdsong and flowers as possible addenda. ${ }^{98}$ As Justus Lipsius (1547-1606) had reminded his readers, such a garden is the perfect setting for an otium busy with reflection. ${ }^{99}$ Before his eulogy of Condé Rapin had pondered the garden as an ideal site for the vie privée in his Hortorum libri VI (1665), whose four songs were dedicated to the flowers, the trees, the water, and the fruits of an ideal garden. Here he describes a man who settled at the banks of the Seine outside of Paris and there cultivated his garden, 'carpens privatæ gaudia vitæ' ('capturing the joys of the private life').100 In Rapin's description of Condé, these horticultural joys are perfectly compatible with the spirited courtly activities of the prince and his circle: 'Ses entretiens, ses promenades, ses chasses, \& tous les autres divertissemens y ont un caractere de grandeur: tout s'y fait noblement, pour répondre mieux à la noblesse de celuy qui est l'ame d'un lieu si charmant'101 ('His conversations, his promenades, his hunts,

98 Curtius E.R., Europäische Literatur und lateinisches Mittelalter, 11th ed. (Tübingen - Basel: $1993[1948]) 202$.

99 Lipsius Justus, De constantia, book 2, chap. 3 (Antwerp, Plantin: 1586 [1584]) 79-84; the example is mentioned in Prosperetti, Landscape and Philosophy 144. For the renaissance garden as a site of 'new forms of self-fashioning, leisure and pleasure', see Samson A., "Locus amoenus: gardens and horticulture in the Renaissance", in Samson A. (ed.), Locus amoenus: Gardens and Horticulture in the Renaissance (Hoboken, NJ: 2012) 1-23, here 1.

100 Rapin René, Hortorvm libri IV cvm dispvtatione de cvltvra hortensi (Paris, Typographia Regia: 1665) 26. The descriptions of the freedom on the rural estate withdrawn from public duty seems reminiscent of De officiis I.2O and the description of the otiosis: 'Multi autem et sunt et fuerunt, qui eam, quam dico, tranquillitatem expetentes a negotiis publicis se removerint ad otiumque perfugerint; in his et nobilissimi philosophi longeque principes et quidam homines severi et graves nec populi nec principum mores ferre potuerunt, vixeruntque non nulli in agris delectati re sua familiari. His idem propositum fuit, quod regibus, ut ne qua re egerent, ne cui parerent, libertate uterentur, cuius proprium est sic vivere, ut velis' ('But there have been many and still are many who, while pursuing that calm of soul of which I speak, have withdrawn from civic duty and taken refuge in retirement. Among such have been found the most famous and by far the foremost philosophers and certain other earnest, thoughtful men who could not endure the conduct of either the people or their leaders; some of them, too, lived in the country and found their pleasure in the management of their private estates. Such men have had the same aims as kings - to suffer no want, to be subject to no authority, to enjoy their liberty, that is, in its essence, to live just as they please'), Cicero, De officiis I.20, 70-71.

Rapin, Du Grand ou du Sublime 6o. 
and all the other entertainments there have a mark of splendour: everything there is done in a noble way, in order better to agree with the nobility of him who is the soul of such a delightful place').

To conclude, our first theme concerns the formal and spatial implications of vie privée. Condé retires from office and he does so at his rural castle in Chantilly which affords a pleasurable, peaceful, and honourable life in congenial circumstances. This is by no means a hidden retreat. In fact La Brune avers that 'l'éclat de sa retraite \& de ses éminentes qualitez attira de toutes les Provinces de la France \& des Etats les plus éloignez une infinité de gens qui voulurent voir les merveilles qu'on en publioit'102 ('the lustre of his retreat and of his eminent qualities drew from all the French provinces and the most remote realms a host of people who wanted to see the marvels that were disseminated about it').

\subsubsection{Self-Mastery}

The connotations of vie privée diverge in a basic polarisation. One strand is associated with idleness and self-indulgence, while the other is associated with insight and self-mastery. ${ }^{103}$ This doubleness joins the vie privée to other notions of leisure, ${ }^{104}$ and gives Condé's biographers the task of rooting out ominous connotations of his vie privée. As the paradigm of a life without civic office, the private condition is haunted by a shadow of idleness, egotism, and luxury that looms over otium as the paradigmatic counterpart to negotium or nec-otium (business) or officium (civic obligations). ${ }^{105}$ Daubenton, for one, is watchful of evil associations:

102 La Brune, Mémoires, book $7,366$.

103 This double set of connotations appears emphatically in the method proposed by the Oratorian Louis Thomassin (1619-1695) for teaching classical topics in a way that is in harmony with Christianity. In chapter 8 , Thomassin discusses 'La vie privée, la retraite, la solitude le silence, preferables à toutes les grandeurs humaines'; in chapter 20 he turns to l'oisivité, l'intemperance de langue, curiosité and 'quelques autres defauts de la vie privée', Thomassin Louis, La methode d'étudier et d'enseigner Chrétiennement \& solidement les lettres humaines par rapport aux lettres divines et aux écritures, book 3, ch. 2.8 and book 3 , ch. 2.20, vol. 3 (Paris, François Muguet: 1682 [1681]) 452-46o, here 452; 612-626, here 612.

104 For the classical implications of otium as leisure, tranquility, carefreeness et al. - be that in a negative or a positive sense - see above all André, L'Otium; for the Renaissance appropriation, see Vickers B., "Leisure and idleness in the Renaissance: the ambivalence of otium I", Renaissance Studies 4.1 (1990) 1-37; idem, "Leisure and idleness in the Renaissance: the ambivalence of otium II", Renaissance Studies 4.2 (1990) 57-104. For a literary perspective, see, e.g., Krause V., Idle Pursuits: Literature and Oisiveté in the French Renaissance (Newark, NJ: 2003).

105 Our texts are likely flavoured by Renaissance appropriations of classical discourses rather than classical discourses per se, see for these appropriations above all Vickers, "Leisure and idleness in the Renaissance I-II". 
Ne pensés pas Chretiens que ce repos fut oisif; si nôtre Prince aime la retraite, ce ne fût pas comme ces ames paresseuses pour goûter les méprisables douceurs d'un repos obscur \& méprisé; ce fut pour s'apliquer à lui-même, pour travailler, \& sur son esprit \& sur son cœur; pour enrichir son esprit des plus belles connoissances, pour orner son cœur des sentimens les plus nobles de la vertu. ${ }^{106}$

Do not think, Christians, that this rest was idle. If our prince loves retreat, the aim was not, like for those lazy souls, to enjoy the despicable pleasures of shady and contemptuous repose. Rather, the aim was to apply himself to himself, to work both on his spirit and his heart; to enrich his spirit with the most beautiful insights; to embellish his heart with the noblest sentiments of virtue.

Instead, the authors delve into the positive associations of the otium. For Rapin, the repose afforded at Chantilly supports Condé's magnanimity and noble reason in a passage which seems to echo the discussion of the retired versus the active life in Cicero's De officiis:

Pour moy, je trouve dans le Sublime de la gloire du repos de la vie douce \& tranquille de Chantilly, une grandeur d'ame, \& une noblesse de raison qui passera dans l'esprit de tous les sages pour bien plus digne du Prince, que tout ce qu'il a fait de grand dans la guerre. ${ }^{107}$

I, for my part, find in the sublime glory of the repose of the sweet and calm life of Chantilly a greatness of soul and a nobility of reasoning that will run in the spirit of all the sages, which is much more worthy of the prince than all of his accomplishments in war.

106 Daubenton, Oraison funèbre 26-27. This passage taps into the longevous discussion of whether the private life is idle and thus by necessity useless to society; this discussion also resonates in de La Mothe Le Vayer François, "Dialogue sur le sujet de la vie privée", in La Mothe Le Vayer François, Dialogues faits à l'imitation des anciens par Oratius Tubero (Mons, Paul de La Fleche: 1671 [1630]) where Philoponus (from Фіגórovos 'lover of toil') and Hesychius (from irou'ia 'rest, stillness, tranquility') discuss the societal and philosophical value of the vie privée.

107 Rapin, Du Grand ou du Sublime 65. Cicero, De officiis I.2O-21 features a discussion of the merits of an active over a retired life, but ascribes the possibility of a courageous and disciplined soul to both states. The 1670 translation of Cicero's works by Pierre du Ryer (1605-1658), however, translated 'fortis animus et magnus' as 'un courage grand \& genereux' ('a strong and generous courage'), in Les oeuvres de Ciceron de la traduction de Monsieur du Ryer, vol. 9 (Paris, Au Palais: 1670) 112. 
This is a life free of pain and passion,

Mais la souveraine perfection d'un lieu si charmant est la douceur qu'on y gouste. Car ce n'est pas de mesme des autres Cours: on ne peut en approcher, que l'on ne ressente du trouble, de l'inquietude, de l'agitation, \& toutes ces sortes de mouvemens que produit l'ambition, qui saisissent le cœur, \& le pénétrent. C'est l'esprit du grand monde où regnent d'ordinaire les défiances, les soupçons, les jalousies, \& tout ce qu'il y a de plus violent dans les passions [...].108

But the highest perfection of such a delightful place is the sweetness that one enjoys there. Because it is unlike that of other courts: we cannot be part of it unless we let go of worry, concern, turmoil, and all those kinds of inclinations that produce ambition, which seize the heart and penetrate it. This is the spirit of the great world where, normally, conflicts, suspicions, jealousies, and all the most violent passions rule.

The passage evokes Stoic apatheia ( $\dot{\alpha} \pi \dot{\alpha} \vartheta \varepsilon l \alpha$, without passion) and Epicurean ataraxia ( $\dot{\alpha} \tau \alpha \rho \xi \xi \alpha$, without perturbation, equanimity), but probably these allusions are to be read in the lightest of veins, and Rapin is at pains to stress that Condé did not feign philosophical knowledge. ${ }^{109}$ Instead he alludes to a much more general motif of self-mastery, observing that the tranquillity that Condé enjoyed in his vie privée rendered him a master of himself - 'cette tranquilité dont il joûit en sa vie privée, qui le rend maistre de luy-mesme.'110 These descriptions are in chime with a view of leisure as a condition of labour characterised by exercises in self-discipline and intellectual pursuits, ${ }^{111}$ and they evoke the classical trope of being with oneself (secum esse) as a starting

108 Rapin, Du Grand ou du Sublime 59. Similar chords are struck in Bergier - de Saligny, De morte Ludovici Borbonii 312-315.

109 Rapin, Du Grand ou du Sublime 62.

110 Ibidem, 55. Condé's self-mastery is also rehearsed in Charles Saint-Evremond's brief stances irregulières "Sur la Retraite de $\mathrm{M}^{\mathrm{r}}$. Le Prince de Condé à Chantilly" which opens: 'Après avoir réduit mille Peuples divers / Par l'effort glorieux d'une Valeur extrême, / Pour vaincre tout dans ce triste Univers / Il ne te restoit plus qu'à te vaincre toi-même' ('Having crushed a thousand different peoples, by the glorious effort of an immense valour, in order to vanquish everything in this miserable univers, remained only for him to vanquish himself') CEuvres meslées de $M^{r}$. De Saint-Evremond, vol. 2 (London, Jacob Tonson: 1705) 391. The second stance lauds the success of this effort, 'Le Vainqueur s'est vaincu, c'est la grande Victoire' ('The vanquisher vanquished himself; this is the great victory'). See also Bannister, Condé in Context 188.

111 Bondanella, "Petrarch's Rereading of 'Otium'" 19-20. 
point for self-improvement. ${ }^{112}$ La Brune underlines the reflexive element: Condé 'faisoit, dans les heures destinées à la retraite, des reflexions continuelles sur tous les évenemens de sa vie, \& en retiroit les leçons tres-importantes pour la conduite de la vie'113 ('during the hours of the day allocated for retreat, he engaged in continual reflections upon all the events of his life, gleaning from it very important lessons for the conduct of life'). He did not keep this insight to himself but generously doled out counsel based on it. ${ }^{114}$

Consistency is one aspect of this self-mastery. Daubenton underlines that the character of the prince remained the same, whether engaged in military pursuits or in leisurely activities. The preacher opens the description of Condé's retreat with the potent statement that 'La Scene change, mais le Prince ne change pas'115 ('the stage changes, but the prince does not change'). Bergier and Saligny also highlight this consistency in character, informing us that Condé's concern for the poor was the same in his retirement (privato / dans sa vie retirée) as it had been when he was leading the army.116 This stability of character, however, competes with a sense of ascent, epitomised in Daubenton's announcement that 'aprés avoir surmonté tout dans sa vie publique, il s'est surpassé lui-même dans sa vie privée'117 ('after having overcome everything in his public life, he surpassed himself in his private life').

Somewhat paradoxically, the self-knowledge and self-mastery that, according to our biographers, characterise Condé's retreat turn him into a savvier homme politique: 'Dans sa retraite, il reconnut lui-même ces defauts \& ces fautes. Il en gemît, \& par ses sages reflexions il devint un nouvel homme. Il devint grand Politique, prudent, doux, civil, \& obligeant' ('in his withdrawal, he himself acknowledged these failings and mistakes. He bemoaned them and, by his wise reflections, he became a new man. He became a great politician, prudent, civil, and accommodating'). According to La Brune, this was in sharp contrast to his previous inclinations which prompted him to behave in the cabinet and at court as if he were at war. ${ }^{118}$ While adding dramatic spice to the portrait, these civic rewards of Condé's retreat play into the general claim that his was an honourable form of leisure. This second theme, self-mastery, thus points us to the existential benefits of the vie privée as a condition that is

\footnotetext{
112 Enenkel (comm.), Petrarca, De vita solitaria 287-296, 330-333.

113 La Brune, Mémoires, book 7, 364.

114 Ibidem.

115 Daubenton, Oraison funèbre 24. For the topos of consistency between private and public life, see the chapters by Merlin-Kajman and Régent-Susini.

116 Bergier - de Saligny, De morte Ludovici Borbonii 170-171.

117 Daubenton, Oraison funèbre 24.

118 La Brune, Mémoires, book 7, 399.
} 
conducive to self-insight and self-control, drawing heavily on classical associations of the otium honestum.

\subsubsection{Religious Retreat}

Early modern religious discourses are one of the domains where priv ${ }^{*}$ words do occur. These words denote the private devotion in the general sense of devotion that is conducted by lay persons rather than the clergy, ${ }^{119}$ or they are more specifically related to the piety of the closet (and the cubiculum, the Kämmerlein, the chambre, and so on) as a spiritual and material place related to the ongoing reappropriation of Matthew 6:6: 'But whenever you pray, go into your room and shut the door and pray to your Father who is in secret; and your Father who sees in secret will reward you'.120 Much scholarly interest related to private devotion turns to the home, often with an Arendtian slant towards

119 See the definition of 'priere vocale priuée' in Suffren Jean, L'année chrestienne ov Le sainct et profictable employ du temps pour gaigner l'Eternité: Où sont enseignées diuerses practiques \& moyens pour sainctement s'occuper durant tout le cours de l'Année, conformement à l'ordre de l'année, inspiré par le S. Esprit à l'Eglise Chrestienne, vol. 1.1 (Paris: Claude Sonnius, 1640-41) 197, discussed in Bruun M.B., "Time Well Spent: Scheduling Private Devotion in Early Modern France", in Maber R. - Barker J. (eds.), Managing Time: Literature and Devotion in Early Modern France (Oxford et al.: 2017) 35-68, here 35. See also the problematisation of the conflation of private and domestic in Longfellow E., "Public, Private, and the Household in Early Seventeenth-Century England", Journal of British Studies 45.2 (2006) 313-334.

120 Biblical references are quoted according to the New Revised Standard Version. Particularly rich in terminological markers is Wettenhall Edward, Enter Into Thy Closet: or, A Method and Order for Private Devotion, 3rd ed. (London, John Martyn: 1670 [1666]) which, for example, reports as a preparation for prayer: 'And when I am now come home [from the Sunday service], I forthwith retire to my privacy for a small space, where my business is Inquiry into my self and suitable address to Heaven', Wettenhall, Enter Into Thy Closet 407, italics from the edition; Vincent mentions Wettenhall's work and devotional books of a similar ilk in Vincent, Privacy: A short History 47-48, but does not dwell upon the deployment of the term 'privacy'. As a second example and as a representative of the Puritan predilection for privacy as a precondition for sincere devotion, Flavel John, Pneumatologia: A Treatise on the Soul of Man (London, J.D. for Tho. Parkhurst: 1698 [1685]), where, among several mentions of privacy, we read: 'I can tell you when and where I have found poor Servants hard at work for Salvation, labouring for Christ, some in the Fields, others in Barns and Stables, where they could find any privacy to pour out their Souls to God in Prayer' Flavel, Pneumatologia 369. For a close analysis of seventeenthcentury British closet culture, see Rambuss R., Closet Devotions (Durham - London: 1998). As Cowen Orlin reminds us, not all closets were religious, Orlin, Locating Privacy 296-326. For individual religious experience and practice as conditioned by circumstances that may be read as an early modern form of privacy, see the chapters by Melion and Wandel in this volume; for the representation of private devotion in public discourse, see the chapters by Nørgaard and Régent-Susini. 
feminine practices. ${ }^{121}$ However, while sometimes taking place in homes, the piety denoted with rriv $^{*}$ words is basically related to the individual believer as opposed to the community or the congregation.

In our texts it is not Condé's religious life that is identified with a priv* word. The circumstances of his vie privée as a retraite, however, readily lend themselves to the religious coding related to the notion of solitude so central to seventeenth-century French devotion. La solitude is a place and a state that comes in many forms, from the ephemeral solitude cut out for prayer in the course of the day carried out in a chamber or a corner of one's home, ${ }^{122}$ or for a longer period of time, in a rural lodging, ${ }^{123}$ to the temporary or life-long withdrawal to a monastery. ${ }^{124}$ Solitude is a temperament or a mindset that potentially involves penitential self-reflection, contemplative absorption, and ascetic practices. The religious benefits of solitude converge somewhat with

121 See, e.g., Corry M. - Faini M. - Meneghin A. (eds.), Domestic Devotions in Early Modern Italy (Leiden: 2018); Ryan S. (ed.), Domestic Devotions in Medieval and Early Modern Europe (Basel: 2020); Brundin A. - Howard D. - Laven M., The Sacred Home in Renaissance Italy (Oxford: 2018); Martin J. - Ryrie A. (eds.), Private and Domestic Devotion in Early Modern Britain (London - New York: 2016); see also the early modern section in Doran J. Methuen C. - Walsham A. (eds.), Religion and the Household (Woodbridge: 2014).

122 Catechisms and devotional manuals encourage believers to withdraw for morning and evening prayers and examination of conscience, Vialart de Herse Felix, L'Escole chretienne, ou l'on apprend a devenir bon Chretien, \& à faire son salut (Châlons, Jacques Seneuze: 1670 [166o]) 588; Cerné Simon, Le pedagogve des familles chrestiennes. Contenant vn Recueil de plusieurs Instructions sur diuerses Matieres (Paris, Pierre de Bresche: 1662) 41; Gondrin Louis Henri de, Catechisme ou instruction chrétienne pour le diocese de Sens (Sens, L. Prussurot: 1669) 41. See also Bruun, "Prayer, Meditation, and Retreat".

123 Aristocratic devouts might stage sojourns at their castles in the provinces as religious retreats, see, e.g., Hillman's description of the pious stays at various country estates, as hosts and guests, of the duchesses de Longueville and Liancourt and the princess de Conti, Hillman J., Female Piety and the Catholic Reformation in France (Abingdon: 2014) 101-125. Funeral orations may cast rural seigniorial life as an instance of religious retreat, as is the case in the description of Leon Bouthillier, Comte de Chavigny (1608-1652) in Noulleau Jean-Baptiste, Le grand Homme d'Estat selon toutes les maximes de la politique chretienne, la seule vraie politique du monde (Rennes, J. Durand: 1653) 22; see also Bruun M.B., "A Private Mystery: Looking at Philippe de Champaigne's Annunciation for the Hôtel de Chavigny", in Melion W.S. - Pastan E. - Wandel L.P. (eds.), Quid est sacramentum?: Visual Representation of Sacred Mysteries in Early Modern Europe, 1400-1700 (Leiden: 2019) 6o6-655, here 617-618.

124 For the annual retreats, see Suffren, L'année chrestienne, vol. 2.1, 676-840; Cerné, Le pedagogve, 298-305, here 299. Some devout aristocrats took up lodging on cloistered precincts; the friends of Port-Royal, men and women, are the most prominent examples of lay people who lodged at or by abbeys, but also other branches of monastic life attracted such blended life-forms, Bruun, "A Solitude" 453. 
the classical virtues of self-knowledge and self-mastery, discussed above, but add to this the sincere turn to God in pious self-reflection. ${ }^{25}$

Among our texts, these chords are struck most vigorously in Daubenton's funeral sermon. The rhetorical countdown to Condé's death begins with the prince hovering at the threshold of withdrawal from the world, but still short of a sincere withdrawal from sinful carnality:

Le Prince vivoit ainsi dans la retraite, pratiquant tous les offices de la vie civile, irreprochable à la Cour même, oû les vertus les plus pures ne sont pas à couvert de la censure, lors que la grace consuma ce qui restoit en lui des cupidités humaines, \& acheva de détacher son cœur du monde, où il tenoit encore un peu; alors le moment tant desiré, le moment du salut arrive. ${ }^{126}$

Thus the prince lived in his withdrawal, practising all the obligations of the civic life [to the extent] of being irreproachable even at court and with not even the purest virtues exempt from correction, when grace consumed what remained in him of human avarice and managed to detach his heart from the world, where he still had some attachment. Then comes the moment so ardently desired, the moment of salvation.

The master-narrative shifts. Condé becomes the penitent Emperor Theodosius to Daubenton's Ambrose, ${ }^{127}$ as Daubenton arrives at the moment when Condé shuts himself up with Père Deschamp for days, reevaluating his life with a broken and lamenting heart. ${ }^{128}$ Daubenton recounts how, from that moment, Condé's disposition changed completely, 'degoûté des vanités mondaines,

125 For the contemplative associations of otium developed in the Christian, above all monastic, tradition, see Leclercq J., Otia monastica: Études sur le vocabulaire de la contemplation au moyen âge (Rome: 1963). See also Enenkel's observation that in the late antique and medieval Christian tradition the classical trope of conversing with oneself in solitude morphed into a conversation with God in prayer and contemplation, Enenkel (comm.), Petrarca, De vita solitaria 291-294.

126 Daubenton, Oraison funèbre 40.

127 In 390 Emperor Theodosius (347-395) revenged an uproar in Thessaloniki by massacring thousands of inhabitants. As a result, Ambrose of Milan (ca. 340-397) excommunicated the Emperor who had to go through a period of penance in order to obtain episcopal forgiveness. In his funeral oration for Theodosius, De obitu Theodosii, Ambrose expounds the need to overcome anger with humility. Theodosius is one of the paradigmatic examples of penitence in Godeau Antoine, Les Tableaux de la penitence (Paris, Augustin Courbé: 1654) 566-586.

128 Daubenton, Oraison funèbre 40. 
jusqu'à faire aux autres des leçons du mépris du monde, il commença à ne plus goûter que vous dans la solitude'129 ('so disgusted by worldly vanities that he taught others the contempt of the world, he began to enjoy nothing but you [God] in his solitude'). He was not shy of this development. Indeed,

[c]e que les ames vulgaires ont honte de faire, le Prince de Condé, comme le grand Theodose, ne rougit pas de donner des marques publiques de son changement, quod privati erubescunt non erubuit imperator publicè agere poenitentiam [.] $]^{130}$

while the base souls are ashamed to do, the prince of Condé like the great Theodosius is not ashamed to give public displays of his change: 'What private citizens blush to do, the emperor did not blush to do, to perform his penitence in public'.

Most conversions, Daubenton avers, are superficial, but like Theodosius Condé persevered in his conversion until the end, and once the world was banished from his heart, it never came back. ${ }^{131}$ Daubenton takes Condé's retreat as his point of departure for a religious discourse on the military hero's conversion into a lover of solitude, conjuring up the vision of the withdrawn prince:

[C]'est le dernier comble de sa grandeur d'voir êté un Prince d'un merite universel, qui a soûtenu le caractere de Heros jusques dans sa vie privée, par des qualités vives et extraordinaires, toutes dans le degré plus heroïque. Arrêtés ici vos regards, Chrestiens, \& admirés encore une fois dans un seul homme toutes les vertus, soit morales ou Chrêtiennes; ce qu'on doit le plus admirer dans sa retraite, est sa retraite même, l'amour de la solitude, ce noble repos si digne de lui \& rempli de tant de dignité[.] $]^{132}$

It is the ultimate culmination of his greatness to have been a prince of universal merit, who maintained his heroic character even into his private life by vivid and extraordinary qualities which all came in the most

129 Ibidem.

130 Ibidem, 41. The Latin quotation is from Ambrose's De obitu Theodosii 34 (Patrologia Latina, vol. 16, col. 1398) which adds the aspect of publicising to a reference on King David's penance from Ambrose's De apologia prophetae David IV.15 (Patrologia Latina, vol. 14, col. 858) which was dedicated to Theodosius.

131 Daubenton, Oraison funèbre 42.

132 Ibidem, 25. 
heroic degree. Behold, Christians, and admire yet again in a single man all the virtues, be they moral or Christian: what should be admired most in his withdrawal, is his withdrawal itself: the love of solitude, this noble repose, so worthy of him and filled with such dignity.

The seventeenth-century devout solitude comes in many shapes. ${ }^{133}$ Desert allusions do not necessarily connote the world-renouncing severity of the early hermits, and Rapin's description of Chantilly as a hermitage, for one, plays on pleasurable rather than ascetic solitude. ${ }^{134}$ Daubenton focuses on the virtue and peace of Condé's solitude. In his underlining of the princely dignity he thus forgoes the penitential tenor that characterises many contemporary descriptions of religious solitude. ${ }^{135}$

Condés libertine past was an obstacle for the fully-fledged religious coding of his vie privée, and Daubenton and Bergier are at pains to underline that he made a pious end. Daubenton avers that the prince approached death 'avec une fermeté plus qu'humains, ni du froid stoïque des esprits hautains, ni de l'insensibilité stupide des ames dures' ('with a superhuman resolve [that came] neither from the stoic cold of proud spirits nor from the stupid ruggedness of hardened souls') because he had known death already, when dying to himself ('en mourant à lui-même'). ${ }^{136}$ Bergier adds that Condé was 'mourant en Prince Chrestien \& Catholique, \& non pas en Philosophe Stoïque' ('dying as a Christian and Catholic prince and not as a Stoic philosopher'). ${ }^{137}$ As we have

133 See Bruun, "A Solitude" 452-455.

134 Rapin, Du Grand ou du Sublime 52, 58. Furetière gives two primary meanings of hermitage, the desert-dwelling of a hermit and the isolated rural abode, built for pleasure and solitary living, Furetière Antoine, Dictionaire universel, Contenant generalement tous le mots françois tant vieux que modernes, \& les Termes de toutes les sciences et des arts, vol. 2 (The Hague - Rotterdam, Arnout et Reinier Leers: 169o) 255.

135 The entire religious spectrum of seventeenth-century France seems bent on solitude. At one end, the Port-Royalist solitude is above all a locus of world-renunciation and unmediated encounters with one's own sin, see, e.g., Le Roy Guillaume, La solitude chrétienne: Où l'on apprendra par les sentimens des saints peres, combien on doit désirer de se séparer du monde, autant qu'on le peut, lors qu'on veut travailler serieusement à son salut, 2nd ed. (Paris, C. Savreux: 1659). See also Nicole Pierre, De la connoissance de soi-même in Essais de Morale contenus en divers traités sur plusieurs devoirs importants, vol. 3 (Paris, Guillaume Desprez and Jean Desessartz: 1714 [1671]) 10. Jesuit piety was more interested in solitude as a locus of spiritual and meditative exercises modelled on Ignatius of Loyola's, see, e.g., the translation of Alfonso Rodriguez's popular exercises in Les exercices de la vertu et de la perfection chrétienne, nouvelle traduction (Paris, Jean Baptiste Coignard: 1674 [Spanish 1609]).

136 Daubenton, Oraison funèbre 45 .

137 Bergier - de Saligny, De morte Ludovici Borbonii 119. 
seen, the notion of vie privée can evoke and be joined to a wide array of different connotations, and for an author who wants to convey a clear message, it is important to make clear-cut distinctions and purge unwanted associations.

This third motif, religious retreat, shows yet another cluster of associations readily activated in connection with Condé's vie privée. The segregation of motifs such as retirement, self-mastery, and religious retreat helps us to gain an overview of associative shades of vie privée. The segregation, however, remains artificial and strained, and we should not forget that in the selected texts these motifs are intertwined, showing that the associations of vie privée are not only mouldable, but also open to mergers with other semantic clusters, be they related to self-insight or world-forsaking.

Part II : Condé's Ultimate Privacy

So far our study of the representations of Condés withdrawal and thus the notion of privacy has hinged on terminology. The examination revolving around the term vie privée targets the term and, secondarily, its semantic charge and context, but, as we have seen, does not necessarily grasp the phenomenon of privacy as an experience of withdrawal and boundary-keeping. I venture, however, to suggest that an instance of the phenomenon of early modern privacy is present in the description of Condé's death.

As Condé, drawn to Fontainebleau by the illness of his grandson's wife, felt death approaching, he called for his confessor Père Deschamps. ${ }^{138}$ In his funeral oration Deschamps's fellow Jesuit, Daubenton, presents Condé's last hours in great detail for the moral benefit of his audience.

Typical of the genre, Daubenton invites his listeners and readers to observe Condé as he models himself on the grandest paragon of retreat: the desert saints and their emulators in abbeys and cells: 'Acourés donc, Chrêtiens à ce spectacle, \& admirés un Prince qui meurt à la Cour comme l'on meurt dans les deserts \& dans les lieux les plus saints'139 ('Then approach, Christians, this

138 See, e.g., Mme de Sévigné's letter to Philippe Moulceau of 13 December 1686, Correspondance, vol. 3, 265. In a letter to her cousin Bussy-Rabutin Sévigné describes how in the course of 24 hours, Condé ordered his obligations as Christian, royal subject, father, and master, facing death with stamina, peace of mind, mellowness, and the esprit that characterised him on the battlefield, letter to Bussy-Rabutin of 15 January 1687 , Correspondance, vol. 3, 273 .

139 Daubenton, Oraison funèbre 44. For the presentation of intimate devotion as a spectacle in funeral orations, see the chapters by Nørgaard and Régent-Susini. 
spectacle and admire a prince who dies at court in the same way as they die in the desert and in the most saintly places').

Having thus cued himself, the preacher conjures up the last hours of Condé's life. First the prince honoured his obligations of charity to the poor, to his servants, and to his friends. Then he received the Communion in his room, trembling as soon as he perceived the presence of the host and thus his God 'dans sa chambre.' 140 The last eight hours of his life he spent in fond conversations with God. ${ }^{141} \mathrm{He}$ sent out his grieving son and daughter-in-law, in order that nothing worldly vied for his affection so that God alone might fill his heart. This sacrificial separation from these two loved ones was the last sacrifice that he offered to the Lord ('il le prie de se retirer afin que rien de creé ne partage ses affections, que Dieu seul domine dans son cœur. [...] cét sacrifice éloignement, dis-je, de ces deux personnes si cheres, fut le dernier sacrifice qu'il offrit au Seigneur'). ${ }^{142}$ In this state of absolute detachment Condé turned to God, exclaiming his last words: videbimus eum sicuti est - 'I shall see him as he is' - which, according to the preacher, undoubtedly opened the heavenly gates for him. ${ }^{143}$ We almost forget that Daubenton was not there with Condé at his ultimate threshold.

With Daubenton's description of Condé's final withdrawal into his chamber in seclusion with God, we approach the notion of privacy from another angle. There are no priv ${ }^{*}$ words in these paragraphs, and we follow instead Daubenton's account of the gradual withdrawal in which Condé sheds, as it were, one existential dimension after another. First he concludes his obligations as the centre of a courtly circle and the master of his household; then he takes leave of his kin, epitomised in his son, closing off his chamber and his heart to terrestrial attachments; eventually he is alone with God, preparing for the ultimate transition into eternity. Daubenton's description of Condé's death differs from that of La Brune. For example, the latter alternates between Condé's deathbed and Louis XV's reading of the princés final submissive letter, achieving a dramatic effect in chime with his overall focus on Condé's tension-filled relationship to the king, ${ }^{144}$ just as he features a good deal more

\footnotetext{
140 Daubenton, Oraison funèbre 46. It is worth remembering that this chamber was at Fontainebleau and thus not Condé's chambre in any strictly proprietary sense.

141 Ibidem.

142 Ibidem, 49. This withdrawal from kin may well be a rhetorical trope; at least La Brune underlines that Condé sent away his son, but longed so much for him that he called him back, La Brune, Mémoires, book $7,387$.

143 Daubenton, Oraison funèbre 49. The exclamation evokes 1 John 3:2b: 'What we do know is this: when he is revealed, we will be like him, for we will see him as he is'.

144 La Brune, Mémoires, book 7, 376-378, 380 (the wording); 388 (the reading).
} 
back-and-forth of kin and advisors. ${ }^{145}$ There may be many reasons for these differences, but it seems clear that Daubenton has prioritised the progressive withdrawal, perhaps owing to his ambition to offer a condensed ars moriendi, showing the ideal steps of departure from the world without any set-backs. ${ }^{146}$

Looking at Daubenton's text with the heuristic zones in mind helps us to see the thresholds that Condé crosses in his final quasi-ritualised hours. The zones alert us to Daubenton's presentation of this terminal chain of events as a traversal of different, yet related, realms of his life: from Condé's charitable obligations vis-à-vis the community, via his rehearsal of the responsible master of the household to the entry into his chamber and further into a spiritual communication with God. These steps are marked by acts of charity, words of farewell, and a closing of doors. Highly localised in character, these thresholds, however, also concern Condé's relations and obligations. Eventually his obligation is only to God. It may seem like a straightforward, progressive peeling off of layers, as it were, of Roessler's onion model. ${ }^{147}$ However, the heuristic zones offer attention to thresholds that the onion does not afford. They also remind

145 Ibidem, $385^{-3} 88$.

146 The good death displayed in the funeral sermon is a mark of the genre that connects it to the abundance of contemporary works aimed to prepare for death such as the Recollect Antoine Lalande's Méthode affective pour assister les malades à mourir saintement (1663), the Capuchin Bernardin de Paris's La Mort des chrestiens formée sur la mort de N.S. Jésus-Christ crucifié (1682), Pasquier Quesnel's Le bonheur de la mort chrétienne: Retraite de huit jours (1689), and Jean Girard de Villethierry's Le chrétien dans la tribulation et dans l'adversité: Le chrétien malade et mourant (1704). To this can be added instructions on dying well embedded in books of spiritual exercises such as Louis-François d'Argentan's Les exercices du chrestien intérieur (1664) whose seventh exercise should be practised monthly to prepare for the good death, or Hubert Jaspart's Solitude interieure (1678) the thirteenth chapter of which is dedicated to the soul approaching death, see Jaspart Hubert, Solitude interieure dans laquelle le solitaire fidèle, comme aussi tout Chrestien [...] trouvera le moyen d'estre, vivre, mourir et operer en Dieu. Nouvelle edition (Paris, Christophe Remy: 1785 [1678]) 157-165. For the genre of ars moriendi, see Rudolf R., Ars moriendi: von der Kunst des heilsamen Lebens und Sterbens (Cologne - Graz: 1957); Chartier R., "Les arts de mourir, 1450-16oo", Annales: Histoire, Sciences Sociales 31.1 (1976) 51-75; Roche D., "La Mémoire de la Mort': Recherche sur la place des arts de mourir dans la Librairie et la lecture en France aux XVII ${ }^{\mathrm{e}}$ et XVIII ${ }^{\mathrm{e}}$ siècles", Annales: Histoire, Sciences Sociales 31.1 (1976) $7^{6-119}$. Seen as the pinnacle of the self-reflection ascribed to Condé's vie privée, this allegedly calm and conscious preparation for death seems to exemplify, albeit in a later period, Schönberger's observation that in the late medieval period the relation to death is an integral moment of human Selbstdeutung ('self-interpretation'), see Schönberger R., "Von der meditatio mortis zur ars moriendi: Das Problem des Todes im Denken des Jean Gerson", in Aertsen J.A. - Pickavé M. (eds.), Ende und Vollendung: Eschatologische Perspektiven im Mittelalter (Berlin: 2002) 721-734, here 727 .

Roessler, The Value 13. See above. 
us that there are overlaps. When Daubenton invites the audience to the spectacle of death in Condé's chamber, he activates a link between the individual, indeed private, death and the community of listeners and readers. By allowing the audience to peer into Condé's imagined intimacy with God, the preacher partly imagines Condé's pious end and devout consistency and partly teaches an instance of privacy and the ideal conduct in privacy. Daubenton's exhibition thus affirms this privacy while disrupting it. The privacy portrayed is a spatially segregated and spiritually concentrated intimacy with God. In this intimacy Condé is turned unconditionally to his creator, unhampered by competing attachments, and his situation thus resembles what seventeenth-century believers would recognise as the condition of the prelapsarian, paradisaical self before it became curved towards its own carnal urges in the Fall. While this privacy may be a place, in casu the chamber, it is thus above all a state, that is, the intimacy with God, reminiscent of the original, unsevered bond of God and human.

\section{5}

\section{Conclusion}

The representations of Condé's withdrawal help us to distinguish the term privé $(e)$, the concept of privacy, and the phenomenon of privacy. The occurrence of the term vie privée is an undeniable given. We can trace the term and the cognates appended to it, vie particulière, vie retirée, solitude, retraite, and so on in texts, and we can study the characteristics ascribed to this life without office denoted in the term vie privée. When searching for the concept of privacy, we enter into more uneven terrain. I suggest that the qualities associated with Condé's vie privée give us a set of components that belong to the composite, but evasive history of this concept. Thus the withdrawal from a form of hustle and bustle, in casu the royal court; a spatial trope, in casu the horticultural delights of Chantilly; and the alleged knowledge and mastery of self all tap into - and contribute to - the seventeenth-century French imaginary of the vie privée. They do, however, also tap into and contribute to a concept of privacy that is accumulated and nuanced across different periods and circumstances. The definitions of privacy as, for example, a right to be let alone, a control of access, or a question of decisional, informational, and localised autonomy feed on this history.

While this vie privée does not equal privacy, I do suggest that Daubenton's representation of Condé's dying hours and his severance of one bond to the exterior, worldly conditions after another offers an early modern instance of 
privacy. Condés ultimate privacy is but one example of a copious and multifaceted discourse which suggests that the religious realm may be one of the areas best fitted for searches for early modern privacy - without forgetting that this is a form of privacy that is intensely surveyed by God and his earthly representatives.

What do we gain by identifying the representation of Condé's death as an instance of 'privacy' rather than simply, for example, as a portrayal of a 'deathbed', a 'chamber', or a 'prayer'? When we apply the notion of privacy, we enable an analytical move from the particularity of Daubenton's text to more general insights based on comparisons across chronological, regional, confessional, as well as class- or gender-related specificities. Such comparisons may evoke the discourse of the prayer in the closet mentioned above or comparisons with death-bed scenes from other funerary sermons. However, it might also make sense to compare this religious privacy with other forms of privacy, be they related to, say, intellectual pursuits in the studiolo, to sexual intimacy, or to conversational secrecy. Invested in such a comparison, Daubenton's presentation of Condé's shedding of obligations and the inherent augmentation of religious authenticity prompts us to look for examples of detachment and achievements in other versions of privacy - even contemporary versions bearing in mind the question: what is sought, what is shed, and what is gained when we enter privacy?

\section{Bibliography}

Altman I., "Privacy Regulation: Culturally Universal or Cultural Specific?", Journal of Social Issues $33 \cdot 3$ (1977) 66-84.

André J.-M., L'Otium dans la vie morale et intellectuelle à Rome des origines à l'époque augustéenne (Paris: 1966).

Arendt H., The Human Condition (Chicago - London: 2018 [1958/1998]).

Ariès P. - Duby G. - Chartier R. (eds.), Histoire de la vie privée, 5 vols. (Paris: 1985-1987). Aumale H. d'Orléans, Histoire des princes de Condé aux XVI et XVII e siècle, 9 vols.

(Paris: $1863^{-1896) .}$

Bannister M., Condé in Context: Ideological Change in Seventeeth-century France (Oxford: 2000).

Battista A.M., "Morale 'privée' et utilitarisme politique en France au XVIIe siècle", in Lazzeri C. - Reynié D. (eds.), Le pouvoir de la raison d'État (Paris: 1992) 191-230.

Beauvalet-Boutouyrie S., La solitude: XVII - XVIII ${ }^{e}$ siècle (Paris: 2008).

Becker A., Gendering the Renaissance Commonwealth (Cambridge: 2019). 
Béguin K., "L'académie du Grand Condé: un asile de la liberté scientifique?", in Demeulenaere-Douyère C. - Brian É. (eds.), Règlement, usages et science dans la France de l'absolutisme (Paris - London - New York: 2002) 25-35.

Béguin K., Les princes de Condé: Rebelles, courtisans et mécènes du Grand siècle (Seyssel: 1999).

Bergier François - De Saligny Louis, De morte Ludovici Borbonii Principis Condcei primi regio sanguine principis; et de prcelare ab eodem in vitâ gestis, epistolce duce (Paris, Jean François Dubois: 1689).

Beugnot B., "Loisir, retraite, solitude: de l'espace privé à la littérature", in Fumaroli M. Salazar P.J. - Bury E. (eds.), Le loisir lettré à l'âge classique (Geneva: 1996) 173-195.

Beugnot B., "Y a-t-il une problématique féminine de la retraite?", in Leiner W. (ed.), Onze études sur l'image de la femme dans la littérature française du dix-septième siècle (Tübingen: 1978) 29-49.

Beugnot B., Loin du monde et du bruit: Le discours de la retraite au XVII ${ }^{e}$ siècle, and ed. (Paris: 2015 [1996]).

Bobbio N., Democracy and Dictatorship: The Nature and Limits of State Power (Minneapolis, MN: 1989).

Bondanella J.C., "Petrarch's Rereading of 'Otium' in 'De vita solitaria”, Comparative Literature 60.1 (2008) 14-28.

Brewer J.D., "This, that and the other: Public, Social and Private in the Seventeenth and Eighteenth Centuries", in Castiglione D. - Sharpe L. (eds.), Shifting the Boundaries: Transformation of the Languages of Public and Private in the Eighteenth Century (Exeter: 1995) 1-21.

Brooke C., Philosophic Pride: Stoicism and Political Thought from Lipsius to Rousseau (Princeton NJ: 2012).

Brundin A. - Howard D. - Laven M., The Sacred Home in Renaissance Italy (Oxford: 2018).

Brunner O. - Conze W. - Koselleck R. (eds.), Geschichtliche Grundbegriffe: Historisches Lexicon zur politisch-sozialen Sprache in Deutschland, vol. 1 (Stuttgart: 1972).

Bruun M.B., "A Private Mystery: Looking at Philippe de Champaigne's Annunciation for the Hôtel de Chavigny", in Melion W.S. - Pastan E. - Wandel L.P. (eds.), Quid est sacramentum?: Visual Representation of Sacred Mysteries in Early Modern Europe, 1400-1700 (Leiden: 2019) 6o6-655.

Bruun M.B., "A Solitude of Permeable Boundaries: The Abbey of La Trappe between Isolation and Engagement", in Göttler C. - Enenkel K. (eds.), Solitudo: Spaces, Places, and Times of Solitude in Late Medieval and Early Modern Europe, Intersections (Leiden: 2018) 451-479.

Bruun M.B., "Prayer, Meditation, and Retreat", in Lyons J.D. (ed.), The Oxford Handbook of the Baroque (Oxford: 2018). 
Bruun M.B., "Privacy in Early Modern Christianity and Beyond:Traces and Approaches", Annali Istituto storico italo-germanico/Jahrbuch des italienisch-deutschen historischen Instituts in Trient 44.2 (2018) 33-54.

Bruun M.B., "Work Method", https://teol.ku.dk/privacy/research/workmethod/privacy _work_method.pdf/PRIVACY_Work_Method_Acces.pdf, accessed on 15 October 2020.

Bruun M.B., “Time Well Spent: Scheduling Private Devotion in Early Modern France”, in Maber R. - Barker J. (eds.), Managing Time: Literature and Devotion in Early Modern France (Oxford et al.: 2017) 35-68.

Castiglione D. - Sharpe L. (eds.), Shifting the Boundaries: Transformation of the Languages of Public and Private in the Eighteenth Century (Exeter: 1995).

Cerné S., Le pedagogve des familles chrestiennes. Contenant vn Recueil de plusieurs Instructions sur diuerses Matieres (Paris, Pierre de Bresche: 1662).

Chartier R., "Les arts de mourir, 1450-16oo", Annales: Histoire, Sciences Sociales 31.1 (1976) 51-75.

Cicero De officiis, trans. W. Miller, Cicero: On Duties, Loeb Classical Library 30 (Cambridge, MA: 1913).

Conan M., "The New Horizons of Baroque Garden Cultures", in Conan M. (ed.), Baroque Garden Cultures: Emulation, Sublimation, Subversion (Washington DC: 2005) 1-35.

Corry M. - Faini M. - Meneghin A. (eds.), Domestic Devotions in Early Modern Italy (Leiden: 2018).

Coste P., Histoire de la vie de Louis de Bourbon, prince de Condé, 2 vols. (Cologne, $\left.\mathrm{F}^{* * * * * *}: 1693\right)$.

Cowan B. - Yetter L. (eds.), Publicity and Privacy in Early Modern Europe: Reflections on Michael Mckeon's The Secret History of Domesticity, special issue of History Compass 10.9 (2012).

Cowan B., "Rethinking Habermas, Gender and Sociability in Early Modern French and British Historiography", in Vanhaelen A. - Ward J.P. (eds.) Making Space Public in Early Modern Europe: Geography, Performance, Privacy (New York: 2013) 41-53.

Curtius E.R., Europäische Literatur und lateinisches Mittelalter, 11th ed. (Tübingen Basel: 1993 [1948]).

D’Angers J.-E, L'Humanisme Chrétien auXVII ${ }^{e}$ siècle: S. François de Sales et Yves de Paris (The Hague: 1970).

Daubenton Guillaume, Oraison funebre de tres-haut, et tres-puissant prince Louis de Bourbon prince de Condé (Dijon, Jean Ressayre: 1687).

Doran J. - Methuen C. - Walsham A. (eds.), Religion and the Household (Woodbridge: 2014).

Dubois E., René Rapin: L'homme et l'œuvre (Lille: 1970). 
Elias N., Über den Prozeß der Zivilisation: Soziogenetische und psychogenetische Untersuchungen (Frankfurt a.M.: 1981 [1969]).

Elias N., On the Process of Civilisation: Sociogenetic and Psychogenetic Investigations, transl. E. Jephcott (Dublin: 2012).

Emmelius C. - Freise F. - von Mallinckrodt R. - Paschinger P. - Sittig C. - Toepfer R. (eds.), Offen und Verborgen: Vorstellungen und Praktiken des Öffentlichen und Privaten in Mittelalter und Früher Neuzeit (Göttingen: 2004).

Ford P., "Lucretius in early modern France", in Gillespie S. - Hardie P. (eds.), The Cambridge Companion to Lucretius (Cambridge: 2010 [2007]) 227-241.

Foucault M., "About the Beginning of the Hermeneutics of the Self: Two Lectures at Dartmouth", Political Theory 21.2 (1993) 198-227.

Foucault M., Sécurité, territoire, population, Cours au Collège de France (1977-1978) (Paris: 2004).

Fumaroli M., "Otium, convivium, sermo: La conversation comme lieu commun", in Fumaroli M. - Salazar P.J. - Bury E. (eds.), Le loisir lettré à l'âge classique (Geneva: 1996) 29-52.

Furetière A., Dictionaire universel, Contenant generalement tous le mots françois tant vieux que modernes, \& les Termes de toutes les sciences et des arts, 3 vols. (The Hague - Rotterdam, Arnout et Reinier Leers: 169o).

Glancy D.J., "The Invention of the Right to Privacy", Arizona Law Review 21.1 (1979) 1-39. Gondrin Louis Henri de, Catechisme ou instruction chrétienne pour le diocese de Sens (Sens, L. Prussurot: 1669).

Goodman D., "Public Sphere and Private Life: Toward a Synthesis of Current Historiographical Approaches to the Old Regime", History and Theory 31.1 (1992) $1-20$.

Habermas J., Strukturwandel der Öffentlichkeit: Untersuchungen zu einer Kategorie der bürgerlichen Gesellschaft (Frankfurt a.M.: 2018 [1962]).

Habermas J., The Structural Transformation of the Public Sphere: An Inquiry into a Category of Bourgeois Society, trans. T. Burger - F. Lawrence (Cambridge: 1989).

Hillman J., Female Piety and the Catholic Reformation in France (Abingdon: 2014).

Huebert R., "Privacy: The Early Social history of a Word", The Sewanee Review 105 (1997) $21-38$.

Jaspart H., Solitude interieure dans laquelle le solitaire fidèle, comme aussi tout Chrestien [...] trouvera le moyen d'estre, vivre, mourir et operer en Dieu. Nouvelle edition (Paris, Christophe Remy: 1785).

Jestaz B., "Documents sur l'œuvre de Jules Hardouin-Mansart à Chantilly", Bulletin Monumental 149.1 (1991) 7-75.

Ker J., The Deaths of Seneca (Oxford: 2010).

Krause V., Idle Pursuits: Literature and Oisiveté in the French Renaissance (Newark, NJ: 2003). 
Kühner C., "Il va de ma vie, de mon honneur et par conséquent de tout'. Die Selbstinszenierung des Grand Condé”, in Asch R.G. - Emich B. - Engels J.I. (eds.), Legitimation - Integration - Korruption: Politische Patronage in Früher Neuzeit und Moderne (Darmstadt: 2011) 115-130.

Kühner C., Politische Freundschaft bei Hofe: Repräsentation und Praxis einer sozialen Beziehung im französischen Adel des 17. Jahrhunderts (Göttingen: 2013).

La Brune Jean de, Mémoires pour servir à l'histoire de Louis de Bourbon, prince de Condé, 2 vols. (Cologne: Pierre Marteau, 1693).

La Fontaine Jean de, CEuvres diverses, ed. P. Clarac (Paris: 1942).

La Mothe Le Vayer François de, Dialogues faits à l'imitation des anciens par Oratius Tubero (Mons, Paul de La Fleche: 1671 ).

Le Roy Guillaume, La solitude chrétienne: Où l'on apprendra par les sentimens des saints peres, combien on doit désirer de se séparer du monde, autant qu'on le peut, lors qu'on veut travailler serieusement à son salut, 2nd ed. (Paris, C. Savreux: 1659).

Leclercq J., Otia monastica: Études sur le vocabulaire de la contemplation au moyen âge (Rome: 1963).

Lipsius Justus, De constantia (Antwerp, Plantin: 1586).

Livius Titus, $A b$ urbe condita, trans. F.G. Moore, Loeb Classical Library 367 (Cambridge, MA: 1943).

Longfellow E., "Public, Private, and the Household in Early Seventeenth-Century England", Journal of British Studies 45.2 (2006) 313-334.

Manning Hope Q., Saint-Evremond and his Friends (Geneva: 1999).

Margulis S.T., "Conceptions of privacy: Current Status and next Steps", Journal of Social Issues $33 \cdot 3$ (1977) $5^{-21 .}$

Martin J. - Ryrie A. (eds.), Private and Domestic Devotion in Early Modern Britain (London - New York: 2016).

Maryks R.A., Saint Cicero and the Jesuits: The Influence of the Liberal Arts on the Adoption of Moral Probabilism, (Aldershot: 2008).

McKeon M., The Secret History of Domesticity: Public, Private, and the Division of Knowledge (Baltimore, MD: 2005).

Melville G. - von Moos P. (eds.), Das öffentliche und private in der Vormoderne (Cologne - Weimar - Vienna: 1998).

Ménestrier C.-F., La Source glorieuse du sang de l'auguste maison de Bourbon dans le coeur de saint Louis, roy de France. Sujet de l'appareil funèbre pour l'inhumation du coeur de très-haut [...] prince Louis de Bourbon, prince de Condé (Paris, E. Michallet: 1687).

Merlin-Kajman H., Public et littérature en France au XVII siècle (Paris: 1994).

Moore Jr B., Privacy: Studies in Social and Cultural History (Armonk, NY: 1984).

Moriarty M., Early Modern French Thought: The Age of Suspicion (Oxford: 2010). 
Nachison B., "Absentee Government and Provincial Governors in Early Modern France: The Princes of Condé and Burgundy, 166o-1720", French Historical Studies $21.2(1998) 265^{-297 .}$

Naudin P., L'expérience et le sentiment de la solitude dans la littérature française de l'aube des Lumières à la Révolution (Paris: 1995).

Nicole Pierre, De la connoissance de soi-même in Essais de Morale contenus en divers traités sur plusieurs devoirs importants, vol. 3 (Paris, Guillaume Desprez and Jean Desessartz: 1714).

Nissenbaum H., Privacy in Context: Technology, policy, and the integrity of social life (Stanford, CA: 2010).

Noulleau Jean-Baptiste, Le grand Homme d'Estat selon toutes les maximes de la politique chretienne, la seule vraie politique du monde (Rennes, J. Durand: 1653).

O'Malley J.W., "Introduction: The Pastoral, Social, Ecclesiastical, Civic and Cultural Mission of the Society of Jesus", in O'Malley J.W. - Bailey G.A. - Harris S.J. - Kennedy T.F. (eds.), The Jesuits II: Cultures, Sciences, and the Arts, 1540-1773 (Toronto: 2006) xxiii-xxxvi.

Orlin L.C., Locating Privacy in Tudor London (Oxford: 2008).

Pardailhé-Galabrun A., La naissance de l'intime: 3000 foyers parisiens $X V I I^{e}-X V I I I^{e}$ siecles (Paris: 1988).

Petrarca Francesco, De vita solitaria, Buch I: Kritische Textausgabe und ideengeschichtlicher Kommentar, ed. K.A.E. Enenkel (Leiden - New York - Copenhagen - Cologne: 1990).

Potts D., Saint-Evremond: A Voice from Exile - Unpublished Letters to Madame De Gouville and the Abbe De Hautefeuille 1697-1701 (Abingdon - New York: 2017).

Prosperetti L., Landscape and Philosophy in the Art of Jan Brueghel the Elder (1568-1625) (Farnham: 2009).

Prosser W., "Privacy", California Law Review 48.3 (1960) 383-423.

Rabutin-Chantal Marie de, Madame de Sévigné: Correspondance, ed. R. Duchêne, 3 vols. (Paris: 1978).

Rambuss R., Closet Devotions (Durham - London: 1998).

Rapin René, Du grand ou du sublime dans les mours et dans les differentes conditions des hommes (Paris, Sebastien Mabre-Cramoisy: 1686).

Rapin René, Hortorvm libri IV cvm dispvtatione de cvltvra hortensi (Paris, Typographia Regia: 1665$)$.

Rapin René, Reflexions sur la philosophie ancienne et moderne, Et sur l'usage qu'on en doit faire pour la Religion (Paris, François Muguet and Claude Barbin: 1676).

Roche D., "La Mémoire de la Mort': Recherche sur la place des arts de mourir dans la Librairie et la lecture en France aux XVII ${ }^{\mathrm{e}}$ et XVIII ${ }^{\mathrm{e}}$ siècles", Annales: Histoire, Sciences Sociales 31.1 (1976) 76-119. 
Roessler B., "Three Dimensions of Privacy", in B. van Der Sloot - A. de Groot (eds.), The Handbook of Privacy Studies: An Interdisciplinary Introduction (Amsterdam: 2018) 138-141.

Roessler B., The Value of Privacy (Cambridge: 2005 [German 2001]).

Rudolf R., Ars moriendi: von der Kunst des heilsamen Lebens und Sterbens (Cologne Graz: 1957).

Rumbold M.E., Traducteur huguenot: Pierre Coste (New York: 1991).

Russell A., The Politics of Public Space in Republican Rome (Cambridge: 2015).

Sales François de, Traité de l'amovr de Diev (Lyon, Pierre Rigaud: 1616).

Samson A., "Locus amoenus: gardens and horticulture in the Renaissance", in Samson A. (ed.), Locus amoenus: Gardens and Horticulture in the Renaissance (Hoboken, NJ: 2012) $1-23$.

Schmale W. - Tinnefeld M.-T., Privatheit im digitalen Zeitalter (Cologne: 2014).

Schneider R.A., Dignified Retreat: Writers and Intellectuals in the Age of Richelieu (Oxford: 2019).

Schönberger R., "Von der meditatio mortis zur ars moriendi: Das Problem des Todes im Denken des Jean Gerson”, in Aertsen J.A. - Pickavé M. (eds.), Ende und Vollendung: Eschatologische Perspektiven im Mittelalter (Berlin: 2002) 721-734.

Seneca, Seneca: Epistles, trans. R. Gummere, vol. 1 (Cambridge, MA: 1917).

Stanton D., "The Ideal of 'repos' in Seventeenth-Century French Literature", L'Esprit Créateur 15.1-2 (1975) 79-104.

Suffren Jean, L'année chrestienne ov Le sainct et profictable employ du temps pour gaigner l'Eternité: Où sont enseignées diuerses practiques \& moyens pour sainctement s'occuper durant tout le cours de l'Année, conformement à l'ordre de l'année, inspiré par le S. Esprit à l'Eglise Chrestienne, 4 vols. (Paris: Claude Sonnius, 1640-1641).

Taormina M., "Noble Selfhood and Saint-Amant's Nature Poetry", in Sabean D.W. Stefanovska M. (eds.), Spaces of the Self in Early Modern Culture (Toronto: 2012) 134-15o.

Thomassin Louis, La methode d'étudier et d'enseigner Chrétiennement \& solidement les lettres humaines par rapport aux lettres divines et aux écritures (Paris, François Muguet: 1682).

Vialart de Herse Felix, l'Escole chretienne, ou l'on apprend a devenir bon Chretien, \& à faire son salut (Châlons, Jacques Seneuze: 1670).

Vickers B., "Leisure and idleness in the Renaissance: the ambivalence of otium I", Renaissance Studies 4.1 (1990) 1-37.

Vickers B., "Leisure and idleness in the Renaissance: the ambivalence of otium II", Renaissance Studies 4.2 (1990) 57-104.

Vincent D., Privacy: A short History (Cambridge: 2016). 
Visé Jean Donneau de, La Feste de Chantilly. Contenant tout ce qui s'est paßé pendant le sejour que Monseigneur le Dauphin y a fait, avec une description exacte du Chasteau \& des Fontaines (Lyon, Thomas Amaulry: 1688).

Von Moos P., “Die Begriffe 'öffentlich' und 'privat”, Saeculum 49 (1998) 161-192.

Von Moos P., Öffentlich' und 'privat' im Mittelalter: Zu einem Problem der historischen Begriffsbildung (Heidelberg: 2004).

Von Moos P., Öffentliches und Privates, Gemeinsames und Eigenes (Berlin: 2007).

Walch A. (ed.), La médiatisation de la vie privée ( $X V^{e}-X X^{e}$ siècle) (Arras: 2012).

Warren S.D. - Brandeis L.D., "The Right to Privacy", Harvard Law Review 4.5 (189o) 193-220.

Weintraub J. - Kumar K. (eds.), Public and Private in Thought and Practice: Perspectives on a Grand Dichotomy (Chicago - London: 1997).

Westin A.F., Privacy and Freedom (New York: 1967).

Wilson B. - Yachnin P. (eds.), Making Publics in Early Modern Europe: People, Things, Forms of Knowledge (New York: 2011).

Winterling A., 'Öffentlich' und 'privat' im kaiserzeitlichen Rom", in Schmidt T. Schmitz W. - Winterling A. (eds.), Gegenwärtige Antike - antike Gegenwarten. Kolloquium zum 6o. Geburtstag von Rolf Rilinger (Munich: 2005) 223-244. 